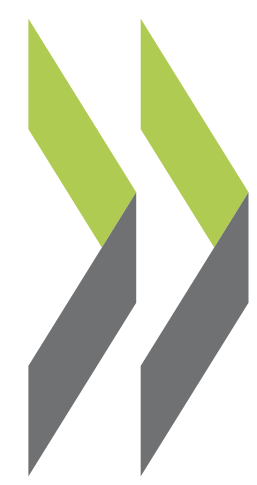

OECD Science, Technology and Industry Working Papers 2006/05

\title{
Valuation and Exploitation of Intellectual Property
}

\section{Shigeki Kamiyama,} Jerry Sheehan, Catalina Martinez 
Organisation de Coopération et de Développement Economiques

Organisation for Economic Co-operation and Development

30-Jun-2006

DIRECTORATE FOR SCIENCE, TECHNOLOGY AND INDUSTRY

English - Or. English

\section{VALUATION AND EXPLOITATION OF INTELLECTUAL PROPERTY}

STI WORKING PAPER 2006/5

Statistical Analysis of Science, Technology and Industry

Shigeki Kamiyama, Jerry Sheehan, Catalina Martinez 


\section{STI Working Paper Series}

The Working Paper series of the OECD Directorate for Science, Technology and Industry is designed to make available to a wider readership selected studies prepared by staff in the Directorate or by outside consultants working on OECD projects. The papers included in the series cover a broad range of issues, of both a technical and policy-analytical nature, in the areas of work of the DSTI. The Working Papers are generally available only in their original language - English or French - with a summary in the other.

Comments on the papers are invited, and should be sent to the Directorate for Science, Technology and Industry, OECD, 2 rue André-Pascal, 75775 Paris Cedex 16, France.

The opinions expressed in these papers are the sole responsibility of the author(s) and do not necessarily reflect those of the OECD or of the governments of its member countries.

http://www.oecd.org/sti/working-papers

(C) Copyright OECD/OCDE, 2006 


\title{
VALUATION AND EXPLOITATION OF INTELLECTUAL PROPERTY
}

\author{
Shigeki KAMIYAMA, Jerry SHEEHAN, Catalina MARTINEZ
}

\begin{abstract}
As firms shift to more open models of innovation based on collaboration and external sourcing of knowledge, they are exploiting their intellectual property, notably patents, not only by incorporating protected inventions into new products, processes and services, but also by licensing them to other firms or public research organisations (PROs), using them as bargaining chips in negotiations with other firms, and as a means of attracting external financing from banks, venture capitalists and other sources.

These developments raise the importance of efficient technology markets and effective IP valuation schemes. Efficient technology markets can improve innovation processes by facilitating exchanges of patented inventions (via sale or licensing) among private and public sector actors that can put inventions in the hands of those most able to commercialise them. Improved valuation can facilitate not only technology transfer, but a full range of channels for exploiting IP such as decision to file a patent and investment in firms which hold patents.

This paper reviews recent evidence and analyses about the current status of valuation and exploitation of patents, with the aim of informing development of related policy. First, it examines the broadening set of channels through which firms aim to exploit their IP. It complements this firm-level perspective with a review of macroeconomic statistics related to the development of technology markets in major geographic regions. Second, the paper reviews various approaches to the valuation of patents. Finally, the paper examines the range of policy initiatives that have been undertaken by governments of OECD countries to foster and improve the valuation and the exploitation of patents.
\end{abstract}




\title{
VALORISATION ET EXPLOITATION DE LA PROPRIÉTÉ INTELLECTUELLE
}

\author{
Shigeki KAMIYAMA, Jerry SHEEHAN, Catalina MARTINEZ
}

\section{RÉSUMÉ}

A mesure que les entreprises s'orientent vers des modèles d'innovation plus ouverts fondés sur la collaboration et l'exploitation de sources externes de connaissances, elles tirent profit de leur propriété intellectuelle, notamment de leurs brevets, non seulement en intégrant des inventions protégées dans des produits, procédés et services nouveaux, mais aussi en les concédant sous licence à d'autres entreprises ou à des organismes de recherche publics, en les utilisant comme monnaie d'échange dans les négociations engagées avec d'autres entreprises et comme un moyen d'obtenir des financements extérieurs auprès des institutions bancaires, des investisseurs en capital-risque et d'autres sources.

Cette évolution rend d'autant plus importants des marchés de technologies et des modèles de valorisation de la propriété intellectuelle efficaces. Des marchés de technologies efficients peuvent améliorer les processus d'innovation en facilitant les échanges d'inventions brevetées (par la vente ou l'octroi de licences) entre des acteurs des secteurs privé et public qui peuvent confier les inventions à ceux qui sont les plus à même de les commercialiser. La valorisation peut contribuer à améliorer non seulement le transfert des technologies, mais aussi les multiples voies utilisées pour exploiter la propriété intellectuelle, par exemple le dépôt d'une demande de brevet ou les investissements dans des sociétés qui possèdent des brevets.

Le présent document fait le point sur des faits et analyses récents concernant la situation actuelle en matière de valorisation et d'exploitation des brevets, afin d'éclairer l'élaboration des politiques dans ce domaine. L'étude porte en premier lieu sur le nombre croissant des canaux par lesquels les entreprises cherchent à exploiter leur propriété intellectuelle. Cette analyse à l'échelle des entreprises se poursuit par l'examen des statistiques macro-économiques liées au développement des marchés de technologies dans de grandes régions. Le document passe ensuite en revue diverses démarches destinées à valoriser les brevets. Enfin, il présente l'ensemble des programmes d'action entrepris par les pouvoirs publics des pays de l’OCDE pour favoriser et améliorer la valorisation et l'exploitation des brevets. 


\section{TABLE OF CONTENTS}

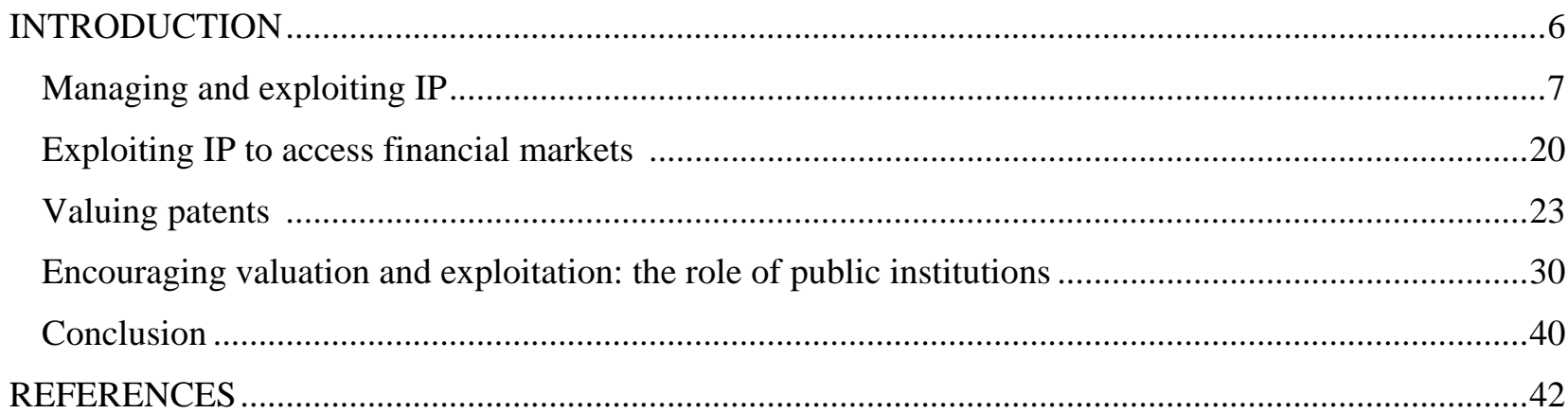

\section{Boxes}

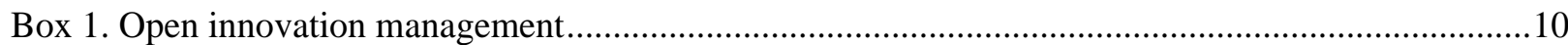

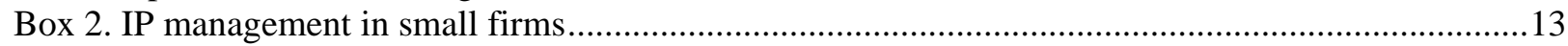

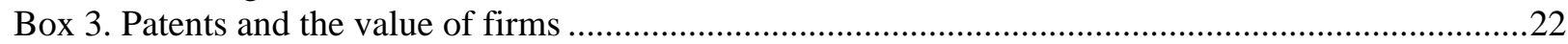

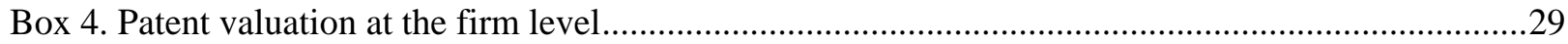

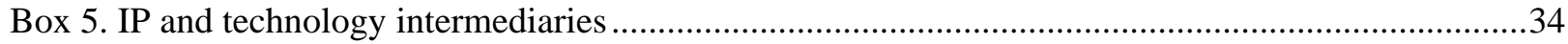

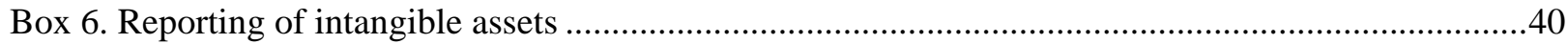




\section{VALUATION AND EXPLOITATION OF INTELLECTUAL PROPERTY ${ }^{1}$}

\section{Introduction}

In knowledge-based economies, intellectual assets such as intellectual property (IP), human capital and organisational capabilities play a crucial role in business performance and economic growth. An increasing share of the market value of firms appears to derive from their intellectual assets, and firms are managing these assets more actively to further enhance their contribution to value creation. This is particularly evident in the case of intellectual property, most notably patents. As firms shift to more open models of innovation based on collaboration and external sourcing of knowledge, they are exploiting their patents in a wider variety of ways: not only incorporating protected inventions into new products, processes and services, but also licensing them to other firms or public research organisations (PROs), using them as bargaining chips in negotiations with other firms, and leveraging them to attract external financing from banks, venture capitalists and other sources.

These developments raise the importance of technology licensing markets and IP valuation schemes. As intellectual property regimes have strengthened in most areas of the OECD, licensing has become a more important channel for diffusing knowledge. Well-functioning technology markets can improve the efficiency of innovation processes by facilitating exchanges of patented inventions (via sale or licensing) among private and public sector actors and putting inventions in the hands of those most able to commercialise them. This and other means of exploiting IP demand effective means of valuing IP. Firm managers, for example, must be able to value patents when determining royalty rates for patent licensing contracts, when estimating the value of a possible merger or acquisition, and when estimating their own corporate value. Financial institutions need to calculate the value of patents when they are used as collateral for bank loans; and investors and financial analysts value patents to assess the value of firms as a basis for their investment decisions and recommendations. Difficulties or inconsistencies in valuation can impede such efforts.

While the private sector has a primary role in driving the expansion of technology markets and advancing valuation of IP, governments can also take action to support and enable such developments. This paper reviews recent evidence and analyses about the current status of valuation and exploitation of patents, with the aim of informing development of related policy. It first examines the broadening set of channels through which firms aim to exploit their IP, with a particular emphasis on technology licensing and access to financial markets. It complements this firm-level perspective with a review of macroeconomic statistics related to the development of technology markets in major geographic regions. Second, the paper reviews various approaches to the valuation of patents, drawing on current business practice and emerging academic research. Finally, the paper examines the range of policy initiatives that have been undertaken by governments of OECD countries to foster and improve the valuation and the exploitation of patents.

$1 \quad$ This report draws on materials presented at the EPO-OECD-BMWA International Conference on Intellectual Property as an Economic Asset: Key Issues in Valuation and Exploitation, held in Berlin on 30 June - 1 July 2005, including the background and issues paper and the summary report (OECD, 2005a and 2005b), both available at www.oecd.org/sti/ipr. 


\section{Managing and exploiting IP}

Firms use their IP in a variety of ways to improve their competitive position, generate revenue and improve their access to financing. One of the more comprehensive surveys of business patenting and innovation patterns (Cohen et al., 2002) found that among various reasons for patenting product innovations, the most frequent among US and Japanese firms were defensive: to prevent copying, prevent other firms from patenting (i.e. blocking) and prevent lawsuits. A smaller, but still significant share of firms indicated that patenting was important for more strategic reasons as well: for use in negotiations (e.g. cross-licensing) to enhance reputation, generate licensing revenue and measure performance (Table 1$)^{2}$

Table 1. Reason for patenting product innovation

$\%$ of respondents and ordinal rank

\begin{tabular}{llc}
\hline & US & \multicolumn{1}{l}{ Japan } \\
\hline Prevent copying & $98.9(1)$ & $95.5(1)$ \\
Patent blocking & $80.3(2)$ & $92.6(2)$ \\
Prevent lawsuits & $72.3(3)$ & $90.0(3)$ \\
Use for negotiations & $55.2(4)$ & $85.8(4)$ \\
Enhance reputation & $38.8(5)$ & $57.9(7)$ \\
Licensing revenue & $29.5(6)$ & $66.7(5)$ \\
Measure performance & $7.8(7)$ & $60.1(6)$ \\
\hline Source: Cohen et al., 2002. & &
\end{tabular}

Recent surveys suggest that an increasing share of companies use patents strategically to create firm value. A recent OECD survey of businesses, for example, found that approximately $60 \%$ of responding firms had seen an increase in both inward and outward patent licences over the previous decade (Sheehan et al., 2004). ${ }^{3}$ Growth in inward and outward patent licensing in the OECD survey was reported more frequently by firms in Asia Pacific and North America than Europe, suggesting room for further development of licensing markets in Europe through measures to help reduce transaction costs including search costs for finding partners, fear of opportunism in negotiation, etc. (Gambardella, 2005).

Indeed many researchers and business executives report that the use of patents has evolved in stages over time, from a focus primarily on defensive applications (e.g. prevent competitors from entering markets, enforcing patents against infringers) to exploitation as part of business and managements strategy (e.g. licensing, building a patent portfolio) to exploitation as a financial asset (i.e. to attract external sources of finance). These stages are cumulative, implying that firms today deploy patents for a broad range of purposes and each stage has a different implication for its valuation (Figure 1). A recent German survey found that use for negotiation ranked fourth behind protection, blocking and reputation-
building. Use for negotiation was found to be especially important for small companies with fewer than 50 employees (BMBF, 2004).

3 Total responses are 105. Sectoral breakdown: Chemicals (excluding pharmaceuticals) (21), Pharmaceuticals (22), Information and communications (13), Machinery (33) and others (16). Geographical breakdown: Asia-Pacific (17), Europe (68) and North America (20). 
Figure1. An illustration of the evolution of IP exploitation and demand for valuation

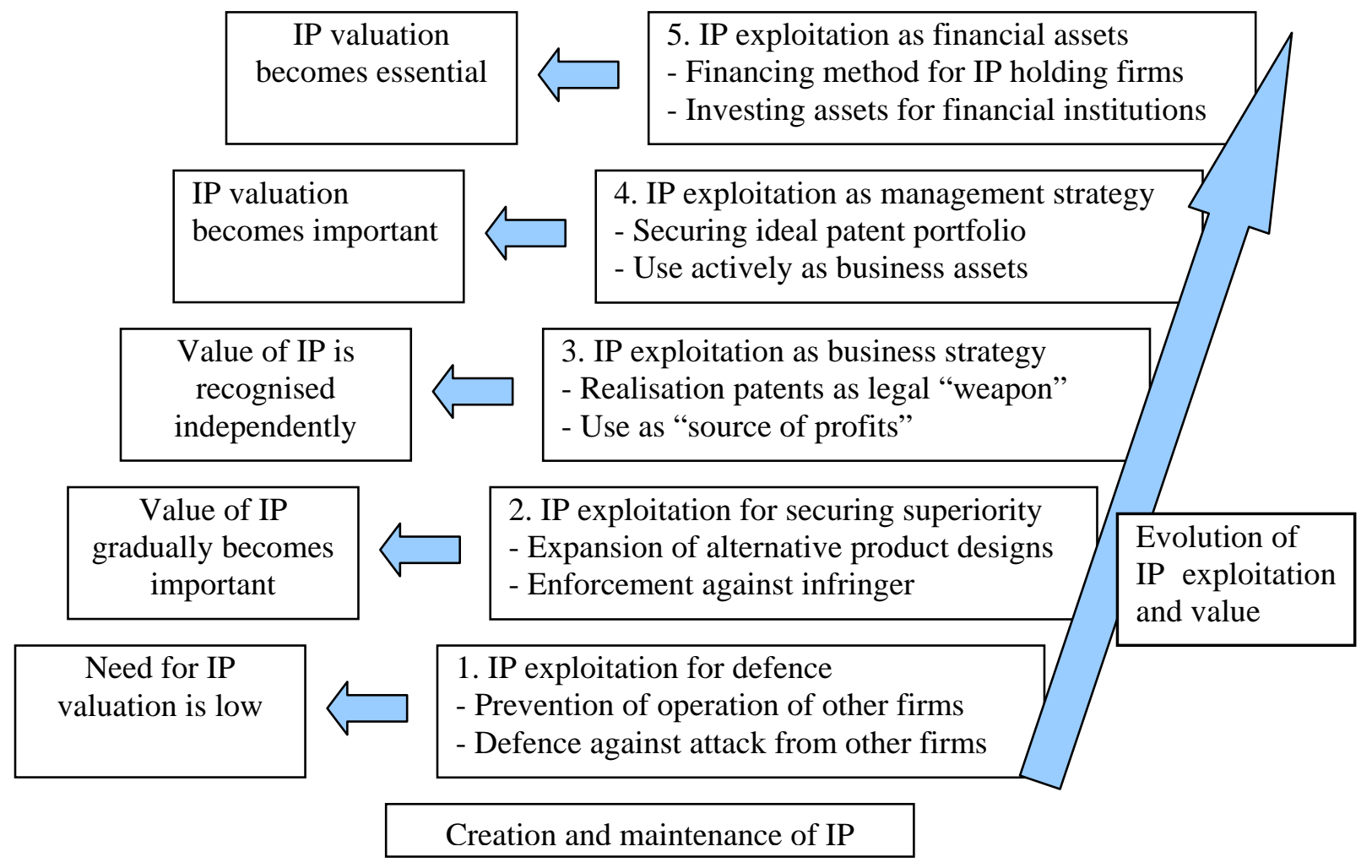

Source: Otsuyama, 2003.

\section{Intellectual asset management and new models of innovation}

In recent years, the concept of intellectual asset management (IAM) has received growing attention from the business community as firms seek to more effectively exploit their intellectual assets - their patents in particular. The basic concept of IAM is to increase the business value from intellectual assets via more comprehensive valuation and management. Firms use IAM to evaluate their patent portfolios and identify patents which have not been used for internal development, but have the potential to be licensed to others without risking their own profitability. They also look for ways to generate cost savings or tax benefits from abandoning or donating to non-profit organisations those patents they do not plan to commercialise themselves. They also defend their patent portfolios more aggressively.

IAM is closely linked to a shift toward more open models of innovation in which firms increasingly rely on external sources of knowledge and technology to complement their internal innovation capabilities (Chesbrough, 2003; OECD, 2002). Such a model of innovation management entails more collaborative research and greater in-sourcing of technology from other innovating organisations, often through technology licences or the acquisition of firms. The open innovation model is perhaps most evident in the information and communications technology (ICT) sector, where it enables firms to cope with accelerating innovation cycles, intensifying global competition, increasingly complex products and services that incorporate multiple technologies and the difficulty of controlling all the intellectual assets and qualified people needed for innovation; (Hirosaki, 2005) (Box 1). Yet, open innovation is also seen in other industries including pharmaceuticals where there is active technology in-sourcing from biotechnology start-ups. While large pharmaceutical firms maintain significant in-house research capabilities, they are increasingly reliant on externally sourced compounds to widen their product lines. About $30 \%$ of the 
revenues of large pharmaceutical firms came from in-licensed drugs in 2001 (Kalamas et al., 2002), and competition has become even more fierce in recent years due to the limited number of available compounds, endowing licensors with stronger bargaining power (Rogers, 1999). Deals for late-stage drugs are on the rise. ${ }^{4}$ While large pharmaceutical firms paid about USD 24 million for late-stage compounds to smaller biotech firms in 1990, they paid an average of USD 76 million for them in 2000 (Picone, 2002). ${ }^{5}$

Interest in IAM is further motivated by the growing appreciation of the extent to which patents are systematically under-utilised. Available statistics show a surge in the number of patents in force around the world: more than 850000 patent applications were filed in Europe, Japan and the United States in 2002, compared to about 600000 in 1992 (OECD, 2004a). By the end of 2002, there were about 5 million patents in force worldwide (EPO et al., 2004). However, several recent surveys indicate that most of these patents do not directly generate revenue for the patent owners via their incorporation into products, processes and services or through licensing revenues:

- A survey by the firm BTG of 150 technology-intensive firms and research universities in the United States, Western Europe and Japan found that 24\% had more than 100 unutilised patents, $12 \%$ had more than 1000 unutilised patents and only 15\% reported had no unutilised patents. Approximately 30\% of Japanese firms reported having more than 2000 unused patents (BTG, 1998).

- A survey of EPO patent applicants (about 700 total responses) showed that the average share of licensed patents in a respondent's patent portfolio in 2003 was 8\% among Japanese firms, 11\% among European firms and 15\% among US firms (Roland Berger, 2005).

- A large scale, comprehensive survey conducted by the Japan Patent Office (JPO) (about 6700 total responses) found that only $30 \%$ of Japanese patents were being exploited internally, less than $10 \%$ were being licensed out to other parties, and more than $60 \%$ of Japanese patents were not being used at all (JPO, 2004). ${ }^{6}$

There are many legitimate reasons for patent holders to refrain from exploiting their patented inventions. Changes in business policies or product market conditions may affect the ability of a firm to introduce related products or services, and the advent of new technologies can make existing inventions obsolete. Alternatively, the decision not to exploit an invention may reflect sound business judgement, balancing the costs of filing, maintaining and protecting patents against the projected benefits of exploitation. Nevertheless, the benefits of improved exploitation can be significant. By adopting IAM processes in its business model, Dow Chemical, for example, increased its IP licensing revenue from USD 25 million to USD 125 million per year and saved USD 50 million in intellectual property costs. ${ }^{7}$ Additional gains may also be possible as the results above were achieved by exploiting $55 \%$ of the firm's patents (as of 2002): 21\% in practice, 9\% used defensively, and 25\% licensed (Hillery, 2004).

\footnotetext{
$4 \quad$ Late-stage compounds are attractive to firms both to reduce risks for drug development and to make immediate revenue streams (Picone, 2002; Rogers, 1999). This is true even though late-stage drugs are 10 times more expensive than early-stage drugs and about one-third of all licensing deals occur at an early stage (Kalamas et al., 2002).

Established pharmaceutical firms are less active in outward than inward licensing. Between 1995 and 1998, only about 50 outward licensing deals were signed by the top ten drug firms in the United States, versus more than 200 inward licences. Possible explanations for the reluctance of top pharmaceutical firms' to engage in outward licensing is the desire to guard their intellectual property, fear that small firms (licensees) may not be successful in further development and successful marketing of end-products, and the low priority for out-licensing assigned by their managements (Rogers, 1999).

The JPO has implemented an annual survey on IP-related activity since 2002. Respondents are asked about: $i$ ) their use of the IPR; ii) the status of their exploitation IPRs; iii) the licensing revenue balance resulting from IPR; iv) operations implemented at IP divisions; and v) IPR infringement suits.
}

7 See www.ipambestpractices.com/Info/GordonP\%20bio.pdf. 
Many large technology-based firms have created independent units to extract value from patents through licensing and other means, and many small and medium-sized enterprises (SMEs) have found that outward-licensing is an effective means for them to obtain economic returns from their R\&D without having to develop all the complementary assets needed for large scale production and distribution.

\section{Box 1. Open innovation management}

According to Botaro Hirosaki, Senior Vice President and Executive General Manager of the Intellectual Assets Operations Unit at NEC Corporation, as shown by a lower Return On Investments (ROI) of firms in IT industry than that of other industries such as automobile manufactures, which successfully achieve high ROI by employing a vertical integrated business model which can control total costs, firms in the IT industry in Japan are faced with changing their business model from the traditional vertical model to more open innovation model.

As high-tech sectors require extensive and costly R\&D that cannot be reduced, the structure of $R \& D$ needs to be adapted to generate additional income to fund it. This requires more openness at each stage of the innovation process: patenting in the early research phase, university collaborations and complementary technology in-sourcing during R\&D phases, licensing out, spinning off, transferring non-core technologies and building alliances in the business development phase. Based on this open innovation model, NEC's IP strategy has the following three main objectives:

Integration with the business strategy by focusing intellectual asset registration on core technologies and standardisation.

- Maximising technological competitiveness by continuously investing in R\&D and in-sourcing promising new technologies.

- $\quad$ Enhancing profit opportunities with licensing-out and technology transfers.

This scheme has been applied by NEC in recent years in different business areas, as illustrated by different business alliances with Siemens (mutual technology transfer and licensing to a new JV and receiving royalty) or SVA Group of China (NEC's technology transfer and licensing to a new JV and receiving royalty).

Source: Hirosaki (2005).

\section{Exploiting patents via licensing}

Licensing is an important element of patent exploitation within firms. Various types of licensing are practiced, including unilateral licensing, cross-licensing and patent pools, all of which involve an agreement by the owner of a patent (licensor) to allow another party (licensee) to make, sell and use the patented invention on an exclusive or non-exclusive basis, without transferring ownership of the patent. Usually, a licensor receives financial rewards in exchange for the licence, typically in the form of royalty payments. Licensing is therefore one suitable mechanism for transferring technology between licensors who want to leverage their technological assets and licensees who want to complement their internal technological capabilities. The advantages and disadvantages of licensing can vary from one case to another (Table 2). In some cases, a patent licence itself is not sufficient to enable a licensee to bring a new product or service to the market because additional know-how is needed, in the form of documentation, software, samples, training and education, and consulting services. 
Table 2: Some advantages and disadvantages of patent licensing

\begin{tabular}{|c|c|}
\hline \multicolumn{2}{|r|}{ Inward-licensing } \\
\hline Advantages & $\begin{array}{l}\text { - } \quad \text { Licence payments tend to be less costly than in-house R\&D. } \\
\text { - } \quad \text { Payment can be used to control risks by designing the payment scheme prudently. } \\
\text { - } \quad \text { Shortens the time required for R\&D and bringing new products into markets. } \\
\text { - } \quad \text { Lower risks when an invention has already been commercialised. }\end{array}$ \\
\hline Disadvantages & - $\quad$ Some restrictions in licensing agreements may raise antitrust concerns. \\
\hline \multicolumn{2}{|r|}{ Outward-licensing } \\
\hline Advantages & $\begin{array}{l}\text { - } \quad \text { High profitability, although revenue streams are uncertain. } \\
\text { - } \quad \text { Allows multiple licensees at the same time. } \\
\text { - } \quad \text { Less risky than Foreign Direct Investment (FDI). } \\
\text { - } \quad \text { Simplicity when a licensee does not need technical advice or know-how, and only paper work } \\
\text { (drafting contract) is needed. } \\
\text { - Especially for SMEs, lowers risk by eliminating need for downstream production facilities. }\end{array}$ \\
\hline Disadvantages & $\begin{array}{l}\text { - } \quad \text { Potentially creates rivals in downstream markets who could erode future profits. } \\
\text { - } \quad \text { Total profit is usually smaller than with successful internal development. } \\
\text { - } \quad \text { Returns largely depend on the capabilities of licensees to develop and market the invention. }\end{array}$ \\
\hline
\end{tabular}

Licensing is widely used as a means of commercialising inventions. In a recent survey of European firms, licensing was the most commonly cited use of patents for generating income (used by $88 \%$ of respondents), followed by an alliance or partnership (61\%), joint venture (56\%) and sale (38\%). However, this is not because licensing is seen as the most promising strategy to generate income. Interestingly, many firms assign a low probability of success to efforts to commercialise an invention via licensing. They tend to view franchising as the most successful method, even though it is used much less frequently (DLA, 2004). The main reasons for the lack of successful commercialisation via licensing may include underperformance of licensees and dissatisfaction with licence agreements due to a lack of negotiation skills.

\section{Generating licensing revenue}

One of the most direct benefits of patent licensing is generating revenue for the patent holder. In recent years, a number of firms have been able to generate considerable royalties from outward licensing of technology. IBM Corp., which started to more actively manage its IPR in the late 1990s and averaged more than 3000 US patent grants a year between 2000 and 2004, received more than USD 1 billion in annual revenues from licensing royalties and sales of IPR; about half of these revenues came from licensing. ${ }^{8}$ Other technology-intensive firms such as DuPont, Merck and Amgen also report significant amounts from patent licensing (Table 3). Texas Instruments reported USD 391 million in licensing revenue in 1992 and was thought to have earned around USD 800 million a year by the end of the decade (Rivette and Kline, 2000). Microsoft Corp. changed its IP management approach to reduce its reliance on copyrights and secrecy in favour of greater reliance on patents, due to the emergence of the Internet and the resulting need for greater openness and transparency in software. Its new intellectual property policy, announced in 2004, is more open to outward licensing of its inventions, which should offset somewhat the costs of inward licensing, which stand at around USD 1 billion. ${ }^{9}$

IBM has received more US patents than any other private-sector organisation for the past 12 years. See: www.uspto.gov/web/offices/com/speeches/05-03.htm. Reported licensing and sale revenues from IP were USD 1.4 billion in 2000, USD 1.2 billion in 2001, USD 0.86 billion in 2002, USD 0.9 billion in 2003 and USD 0.86 billion in 2004. Data from annual corporate reports.

Summary of remarks by David Kaefer, Director of Business Development, Microsoft Corporation at the OECD Forum on Business Performance and Intellectual Assets, 6 October 2004. See www.oecd.org/dataoecd/51/13/33848750.pdf. 
Table 3. Reported licensing revenues

Millions of USD

\begin{tabular}{lcccccc}
\hline Firm (industry) & 2000 & 2001 & 2002 & 2003 & 2004 & $\begin{array}{c}\text { \% of net income } \\
\text { (latest available) }\end{array}$ \\
\hline $\begin{array}{l}\text { DuPont (chemicals) } \\
\begin{array}{l}\text { Merck } \\
\text { (pharmaceuticals) }\end{array}\end{array}$ & 160 & 155 & 128 & 141 & 151 & 8 \\
$\begin{array}{l}\text { Amgen } \\
\text { (biotechnology) }\end{array}$ & 181 & 253 & 332 & 383 & N.A. & 17 \\
IBM (computing) & 528 & 465 & 351 & 338 & 393 & 5 \\
\hline
\end{tabular}

Source: Corporate reports.

Japanese and European firms also profit from licensing, especially in the ICT sector. In recent years, Sony Corp. and Canon Inc. earned roughly JPY 29 billion and JPY 20 billion per year, respectively, from their patent licensing activities (Baba, 2003). NEC already earns more than JPY 10 billion annually from patent licensing (Baba, 2003); to increase its licensing activity, it launched in 2003 a searchable database listing patents that are available for licensing to third parties as part of its open innovation strategy. ${ }^{10}$ Among European firms, Thomson successfully increased its licensing revenue from EUR 278 million in 1999 to 462 million in 2003, accounting for 5.5\% of 2003 total net sales. Thomson has approximately 40900 patents and pending applications and 750 licensing agreements relating to a diversified mix of video products and services. Thomson's top ten licensees account for approximately $72 \%$ of its total licensing revenues (Thomson, 2004).

There are, of course, limits to the ability of firms to profit from the licensing of patented inventions. Some firms are reluctant to do so for fear of losing their competitive advantage. They therefore limit technology licensing to firms that operate outside their fields of business (Peters, 2005). For example, Hitachi, which was one of the top licensors in Japan and was reported to have earned licensing revenues of JPY 43 billion in FY 2002, changed its licensing policy in 2003 from one of openness to third party licensing to a more closed approach that aims to preserve its competitive advantage in the marketplace through greater control of inventions (Takahashi, 2005). This strategic change resulted, in part, from the rapid technology improvement of competitors in Korea and China. Though it is not clear this change will be widespread among firms that currently pursue an open licensing strategy, holding strong patents seems to be a key factor for success.

At the same time, it must be recognised that firms can benefit financially from their patents in indirect ways. Some firms put patents into the public domain or offer non-exclusive, royalty-free licences in order to foster development of a particular field of business in which they hope to operate. This approach can also be used to establish an industry standard that might benefit the patent holder. ${ }^{11}$ These strategies do not bring royalty income, but result in indirect benefits such as establishing de facto standards rapidly and enhancing the reputation of the patent holder. Similarly, many firms view the expenses associated with inward licensing of patents not as a cost (or loss of revenue) per se, but as a means of preventing patent infringement and costly litigation. Some firms are monitoring potential infringements of their patents in order to generate future licences or cross-licences. In a recent survey of patent licensing, for example, Japanese firms (especially large firms) reported that warnings of infringement were the most frequent stimulus to licensing, ahead even of the publication of patent documents (JTM, 2000).

$10 \quad$ For further details see www.ipr-nec.com/en/.

11 For example, in 2005 IBM announced open access to 500 IBM software patents to individuals and groups working on open source software and proposed to develop a patent commons to spur innovation in this area. Subsequent announcements made available sets of patents related to use of ICT for health and education. See: http://www1.ibm.com/businesscenter/venturedevelopment/us/en/featurearticle/gcl_xmlid/26770/nav_id/inthenews. 


\section{Engaging small firms in innovation networks}

Licensing can also improve the ability of small firms to participate in innovation networks and economic value chains. In many industries, small firms lack the scale, scope or market power to fully extract value from their patented inventions. While they can attempt to integrate downstream manufacturing and distribution facilities into their businesses to boost returns from their innovation investments, the associated costs and risk of failure are high. Alternatively, many small firms choose to cooperate with established firms to gain access to such complementary assets. In such cases, patents can be an effective mechanism for technology transfer, allowing the small firm to profit from royalty streams generated by the sales of products and services offered by other firms based on its inventions (Box 2). Inward licensing can also enable small firms to access the technology they need to complement their more limited R\&D portfolios and bring new products and services to market.

IP regimes strongly influence the decisions of small firms to commercialise inventions on their own or in partnership with other, usually larger, firms. Research indicates that strong IP protection regimes are conducive to licensing between small and large firms and enable co-operation that can bring together the complementary assets of participating organisations (Gans and Stern, 2003). In weaker IP protection regimes, start-ups and other small firms may need to acquire complementary assets directly to avoid losing their comparative advantage. Research further suggests that technology-intensive small firms and start-ups can improve their negotiating position with larger firms (e.g. in cross-licensing arrangements) if they have a strong patent portfolio (Grindley and Teece, 1997). It has also been found that increases in the strength of patent protection (e.g. increasing duration, breadth of protection and decreasing costs of application) leads to increased patenting by both large and small firms, but only smaller firms without complementary assets tend to increase licensing. Larger firms tend to license less as patent regimes strengthen (Arora and Ceccagnoli, 2005).

\section{Box 2. IP management in small firms}

Pro-active IP strategies can make a difference for small firms in the marketplace. Successful examples of start-ups whose business models are based on patents can be found in the ICT and biotechnology sectors as well as other industries. Fabless semiconductor firms, for example, design custom chips that are produced in separate foundries or are sold to larger semiconductor manufacturers. A number of biotechnology firms that focus on research to identify new drug targets or new research tools have also seen considerable success as their inventions are subsequently licensed to larger pharmaceutical or health sciences companies for commercialisation.

The success of both types of firms is highly contingent on their ability to protect their IP through patenting. The patents can not only be licensed to other firms, but can facilitate inflows of venture capital.

The importance of a pro-active IP strategy is not limited to ICT and biotechnology firms. For example, the company $t$ blade, a German manufacturer of ice hockey equipment, demonstrates that a small company owning an innovative technology, protected with patents, trademarks, know-how and a technological competitive edge, but lacking direct access to its market, can create value and be successful by sharing knowledge and licensing-out its technology. The business of t-blade consists primarily of replacement blades for ice skates, and it relies on non-exclusive partnerships with brand manufactures. Sharing the ownership of new distribution channels via joint ventures with major players proved to be a successful strategy for t-blade, whose success has also been possible because it protected its technology and know-how in different ways (not only with IPRs) and made IP fully part of the company's strategy (Kunz, 2005).

The t-blade case suggests that a small company can use its IP to access markets by licensing out its technology and entering into joint ventures with distributors. In order to survive, grow, drive profits and cope with technological change, SMEs need to be competitive and protect their innovations. In this respect, patents do contribute to protect market position, create business value, give access to capital and establish a brand.

\section{Sectoral differences}

Patent licensing practices also differ from one industry sector to another, reflecting differences in the dynamics of innovation and the role of patenting in innovation processes. Anand and Khanna (2000) attempt to identify differences across industries with respect to patent licensing based on information from 
the SDC strategic alliances database. They examine licensing contracts involving US participants between 1990 and 1993. The main findings of their study include:

- Licensing is concentrated in selected industries. About $80 \%$ of licensing deals occur in three industries, $46 \%$ in the chemical industry including drugs, $22 \%$ in the electronic and electrical equipment industry including semiconductors and $12 \%$ in the industrial machinery and equipment industry including computers.

- $\quad$ Prior relationship is important to engage in licensing contracts. About $30 \%$ of licensing deals are signed between parties having a prior relationship. This tendency is observed more in computer and electronics firms than in chemicals.

- Exclusivity and restriction clauses are more common in chemical firms. More than half of the deals in chemicals involve some exclusivity clauses, which are less common in computers (18\%) and electronics (16\%). Restrictions such as field of use, geographic domain and contract length are more common in chemicals (40\%) than computers and electronics (30\%).

- Cross-licensing is frequently used in electronics. Cross-licensing is more common in electronics (20\%) than other industries (10\%). This arrangement is observed more for transfers of technology not yet developed than ex-post transfers. ${ }^{12}$

Another study, also based on information from the SDC database on strategic alliances but using more recent data (1985-2002) finds similar results and identifies several factors that affect positively the likelihood of firms to engage in licensing agreements (Vonortas and Kim, 2004). Companies will tend to engage in licensing agreements: the closer their technological profiles; the closer their market profiles; the more familiar they are with each other through prior agreements; the higher their prior independent experience with licensing; and the stronger the intellectual property protection in the primary line of business of the licensor. All these factors affect licensing transaction costs and indicate that reducing transaction cost may be more important when licensing occurs across sectors, whereas strategic and competition-related factors may be more important when licensing occurs between firms pertaining to the same industry.

\section{Enhancing access to patents}

While licensing can be seen as a way of enhancing diffusion of patented inventions, it may not be sufficient. Firms in science- and technology-based industries, such as ICT and biotechnology increasingly conduct business in areas densely populated by patents, which may sometimes overlap and create what are referred to as patent thickets. In such situations, infringing other patents may be unavoidable, even unintentionally, and the prospects for negotiating licences for all necessary technologies are daunting. For example, more than 90000 patents generally related to microprocessors are held by more than 10000 parties (FTC, 2003), and the propensity to patent semiconductor inventions increased, from about 0.3 to 0.6 patents per million dollars of R\&D spending between 1982 and 1992 as large semiconductor firms entered into patent portfolio races to reduce the hold-up problem posed by other patent holders and used them as bargaining chips to obtain favourable terms in negotiations with other patent holders. ${ }^{13}$ On the other hand, since 1982, new entrants (in particular, design firms without manufacturing facilities) patented more aggressively than pre-1982 entrants to attract venture capital funds and secure proprietary rights in niche product markets.

12 This trend is also observed in Japan. Indeed, the ratio of cross-licence to out-licence is about $90 \%$ in the electronics industry, while the ratio accounts for less than $20 \%$ in the chemical industry (JPO, 2004).

Patent intensity declined in the pharmaceutical industry between 1982 and 1992, from about 0.2 to 0.1 patents per million dollars of R\&D. Hall and Ziedonis (2001) attribute the high propensity to patent in the semiconductor industry to a series of pro-patent changes during those years, such as the establishment in 1982 of the US Court of Appeals for the Federal Circuit (which hears IPR-related cases), Polaroid's successful patent infringement suit against Kodak and the successful assertion of patents in courts by firms such as Texas Instruments. 
Practical solutions to obtain room for manoeuvre in environments where patent thickets abound include the use of cross-licensing agreements and patent pools (Shapiro, 2001).

- Cross-licensing agreements involve an exchange of two or more patent portfolios and are typically used to allow the mutual use of patents by multiple patent holders in order to secure freedom of operation (avoid running the risk of entering into patent infringement litigation with other firms operating in similar product markets) and access complementary technologies. As the number of patents required to manufacture products becomes larger, firms tend to engage in cross-licensing agreements involving all current and future patents within a particular field-of-use without making specific reference to individual patents to reduce transaction costs. Although a primary purpose of cross-licensing is to secure freedom of operation, establishing a balancing royalty payment scheme from the owner of the weaker patent portfolio to that of the stronger portfolio may be important as a source of revenues and requires valuing the patents involved in the deal, which might substantially increase transaction costs (Grindley and Teece, 1997).

- $\quad$ Patent pools typically consist of the collection of patents required to offer a product or service. One of the advantages of patent pools from the licensee's perspective is that it becomes a onestop-shop for the set of pooled patents, which can help reduce costs associated with royalties and negotiation. To maximise the benefits of a patent pool, it is important to collect as many required patents as possible while keeping total royalty payments commercially reasonable. The design of the incentive scheme for encouraging patent holders to join a patent pool is important, especially as regards those patent holders who might wish to remain outside the pool and to demand high royalties for their related patents. Kato (2003) considers two possible approaches to this problem. A differentiated royalty approach allows different royalties to apply to different patents, based on their value. An antitrust law approach may apply when a royalty demanded by an outsider is extraordinarily high compared to those demanded for patents within the pool. This can indicate an abuse of patent rights and lead to antitrust suits. The threat of an antitrust suit and related transaction costs may lead the outsider to lower its royalties and join the patent pool.

A number of patent pools associated with technological standards are found in the ICT sector, which requires numerous numbers of essential patents. An illustrative example of a patent pool in the ICT industry is the MPEG-2 patent pool which collects patents covering the MPEG-2 standard. The pool successfully cleared antitrust concern with a de facto approval from regulatory authorities by including only essential, complementary patents - not substitute patents - which is one of the major determinants of an approval for patent pools. However, at the time of its formation, there were disagreements regarding the royalty rate. Some patent holders sought to profit from the MPEG-2 by selling products based on the standard rather than from licensing their patents, and hence sought low royalty rates. Others sought greater licensing revenues and hence a higher royalty rate. Still other firms who thought they held critical patents attempted not to join the pool so they could charge a separate, higher royalty rate (Lerner et al., 2003). In the end, a lower rate was adopted, even if not all firms joined the patent pool. MPEG-2 patents were widely licensed and this is recognised as one of the most established and successful patent pools. Concerns also have been voiced in the biotechnology industry that as the number of patented research tools needed for drug developments increases, R\&D could be impeded because of the difficulty in assembling the 


\section{DSTI/DOC(2006)5}

necessary patents and formidable costs that might be involved. ${ }^{14}$ Patent pools have been suggested as a possible solution to this problem (USPTO, 2000; JPO, 2002). ${ }^{15}$

The magnitude of the effect of patenting on research access to inventions is not clear. A recent survey on biomedical researchers in universities, government, and non-profit institutions yields similar findings to an earlier study (Walsh et al., 2003) that showed little evidence of R\&D being terminated due to difficulties in getting licences from multiple IP owners. Out of 32 respondents who were aware of relevant IP from third-parties, four reported a change in their research plans and five reported delays in their research, but none reported abandoning their research (Walsh et al., 2005). Another recent survey by the American Association for the Advancement of Science (AAAS), however, found that $40 \%$ of the 179 respondents - including $76 \%$ of those in the biosciences industry - reported their research was affected by difficulties in accessing patented technologies: 58\% reported delays, 50\% reported changes in their research plans, and 28\% abandoned their research. Overly-complex licensing negotiations (58\%) were the most common reason for changing or abandoning research, followed by high individual royalties (49\%) (Hansen et al., 2005). As innovation becomes more science-based, and multi-disciplinary research draws together researchers and innovators from different fields with different practices for protecting IP, limitations on research access could become more widespread. ${ }^{16}$ Governments will need to monitor the situation to determine if additional steps are needed to facilitate research access.

\section{Measuring technology markets}

The size and evolution of technology licensing markets is difficult to measure at the national or regional level, because of a lack of robust statistics. Most patent licensing is based on private contracts that are subject to confidentiality agreements, meaning that comprehensive time-series data on patent licensing are not available. ${ }^{17}$ Accounting rules do not require firms to disclose patent licensing revenues as a separate item in corporate reports, and although most OECD countries have regulatory requirements for reporting licensing contracts, these are mostly related to cross-border transactions, and data is published only at an aggregate level. As a result, disclosure of patent licensing activity depends largely on firm policy, and even though disclosure of information of licensing revenues has been shown to have a positive effect on investors (Gu and Lev, 2004), most firms elect not to make such information public. ${ }^{18}$ Hence, available data on patent licensing is limited, scattered, and lacking in uniformity in spite of a greater demand for systematic data, especially from academic researchers, which could help better evidence-based policy making as well as investors. Nevertheless, some general observations can be made.

\section{Global patterns of patent licensing}

Available information suggests that markets for technology are large and growing. In the United States, it has been estimated that patent licensing revenues rose from USD 15 billion in 1990 to more than USD 100 billion in 1998, and experts estimated that revenue could top half-trillion dollars annually by the

\footnotetext{
14 This situation is commonly referred to as "the tragedy of the anti-commons", which is the antithesis of "the tragedy of the commons", which arises when people tend to over-use resources when resources are owned in common. On the contrary, the tragedy of the anti-commons occurs when resources are privatised by multiple owners, and people tend to under-use resources due to difficulties of negotiations of permission to use resources with owners. See Heller and Eisenberg (1998).

Pooling patents related to DNA chips has been suggested in Japan (JPO, 2002). The United States Patent and Trademark Office (USPTO) published a white paper in 2000 discussing the benefits of pooling biotechnology patents (USPTO, 2000).

This was one of the conclusions of a conference on Research Use of Patented Inventions organised by the OECD, the Spanish Research Council and the Spanish Patent and Trademark Office in May 2006.

Some patent-related laws stipulate registration of licences; however, most licensing contracts are not registered.

Based on their survey, Gu and Lev (2004) estimate roughly half of the firms conducting patent licensing do not disclose their royalty income.
} 
middle of the next decade (Rivette and Kline, 2000). A recent Japanese survey indicates that inward licensing increased from JPY 230 billion in 1994 to JPY 360 billion in 2001, while outward licensing jumped from JPY 170 billion in 1994 to JPY 420 billion in 2002 (Motohashi, 2005). Another conservative estimate indicates that total worldwide licensing transactions (including domestic and international transactions) averaged more than USD 36 billion a year between 1990 and 1997 - considerably higher than the estimated average of USD 5.6 billion in the 1980s (Arora et al., 2001). This estimate includes the value of licensing and royalty payments, equity investments and R\&D funding provided in return for licensing rights.

Regional differences in the development of technology licensing markets can also be observed through payments and receipts of royalties of three regions. A survey conducted by the European Patent Office in 2004 found that spending on inward licensing was equivalent to $5.6 \%$ of spending on R\&D for firms in the United States, $22.0 \%$ for firms in Japan, and $0.8 \%$ for firms in Europe respectively; royalty receipts amount to $6.0 \%, 5.7 \%$ and $3.1 \%$ of $\mathrm{R} \& \mathrm{D}$ spending in the United States, Japan and Europe, respectively. These findings are generally consistent with results of an earlier survey by BTG, which found that spending on inward licensing during the 1990s was equivalent to $12 \%$ of R\&D spending in the United States, $10 \%$ in Japan, and 5\% in Europe (Gambardella, 2005). A more recent study, however, found that total inward-licensing in Japan remained about 3\% to 4\% of R\&D spending between 1994 and 2002, while outward licensing expenditures increased from $0.06 \%$ to $0.14 \%$ of total sales revenues (Motohashi, 2005).

Licensing appears to be concentrated in high-technology sectors. In the OECD survey, respondents from the ICT sector were the most likely to report increases in outward licensing (about $80 \%$ of respondents), suggesting that licensing-out has become important as a source of revenue for ICT firms. In contrast, respondents from the pharmaceutical industry were most likely to report increases in inwardlicensing (about $80 \%$ of respondents), reflecting the trend of license-in from small biotechnology firms. Across all sectors, around $70 \%$ of respondents expected the importance of inward and outward patent licensing to grow in the next five years (Sheehan et al., 2004). A recent study in Japan found similar results, with the pharmaceutical and ICT industries being the two dominant sectors for the share of inward and outward licensing between 1994 and 2002, and with smaller and younger firms using licensing more frequently than larger, established firms (Motohashi, 2005).

\section{International licensing}

International licensing also appears to be on the rise and accounts for a significant share of total patent licensing. Receipts from world-wide international licensing appear to have grown steadily since the mid1980s, consistent with growth in the number of US patent applications per unit of R\&D (Arora, 2005). International receipts for intellectual property (including patents, copyrights, trademarks, etc.) increased from USD 10 billion in 1985 to approximately USD 110 billion in 2004, with more than $90 \%$ of the receipts going to the three major OECD regions: European Union, Japan and the United States (Figure 2). Total payments showed a similar trend, climbing to approximately USD 120 billion in 2004, up from USD 8.3 billion in $1985 .{ }^{19}$ While receipts remain considerably higher in the United States than in the EU or Japan, growth rates in the latter have been equal or faster over the past 20-year period.

The definition of payments and receipts for licensing used by the World Development Indicators (WDI) of the World Bank is "Royalty and license fees are payments and receipts between residents and nonresidents for the authorized use of intangible, nonproduced, nonfinancial assets and proprietary rights (such as patents, copyrights, trademarks, industrial processes, and franchises) and for the use, through licensing agreements, of produced originals of prototypes (such as films and manuscripts)". 
Figure 2. Receipts from international licensing in major OECD regions

Billions of USD

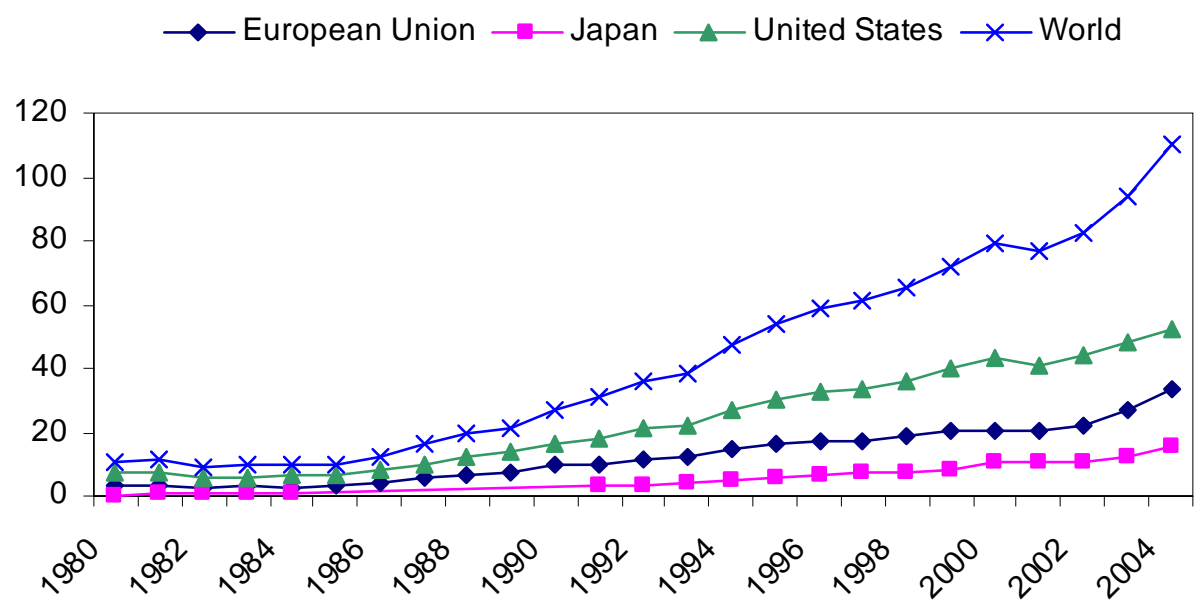

Source: OECD based on World Bank, World Development Indicators Database, June 2006.

At the national level, indicators of technology licensing also show significant increases. In European countries, OECD data on receipts from international licensing and transfers of patents show steep increases in France and Germany during the 1990s (Figure 3). In France, receipts increased by more than a factor of seven between 1990 and 2003 from EUR 330 million to EUR 2.4 billion (not taking into account inflation), while in Germany they doubled from EUR 1.3 billion to EUR 2.7 billion. In contrast, receipts remained relatively flat in Italy at roughly EUR 200 million to EUR 300 million per year. In Japan, patent licensing revenue from foreign parties totalled JPY 340 billion in fiscal year 2002, and Japanese firms spent approximately JPY 210 billion on foreign licenses, yielding a surplus of JPY 130 billion (Figure 4). Other work indicates that international licensing has increased significantly in Japan since 1994 and accounts for most of the increase in total licensing activity (Motohashi, 2005).

Figure 3. Receipts from international patent licences and sales in Europe

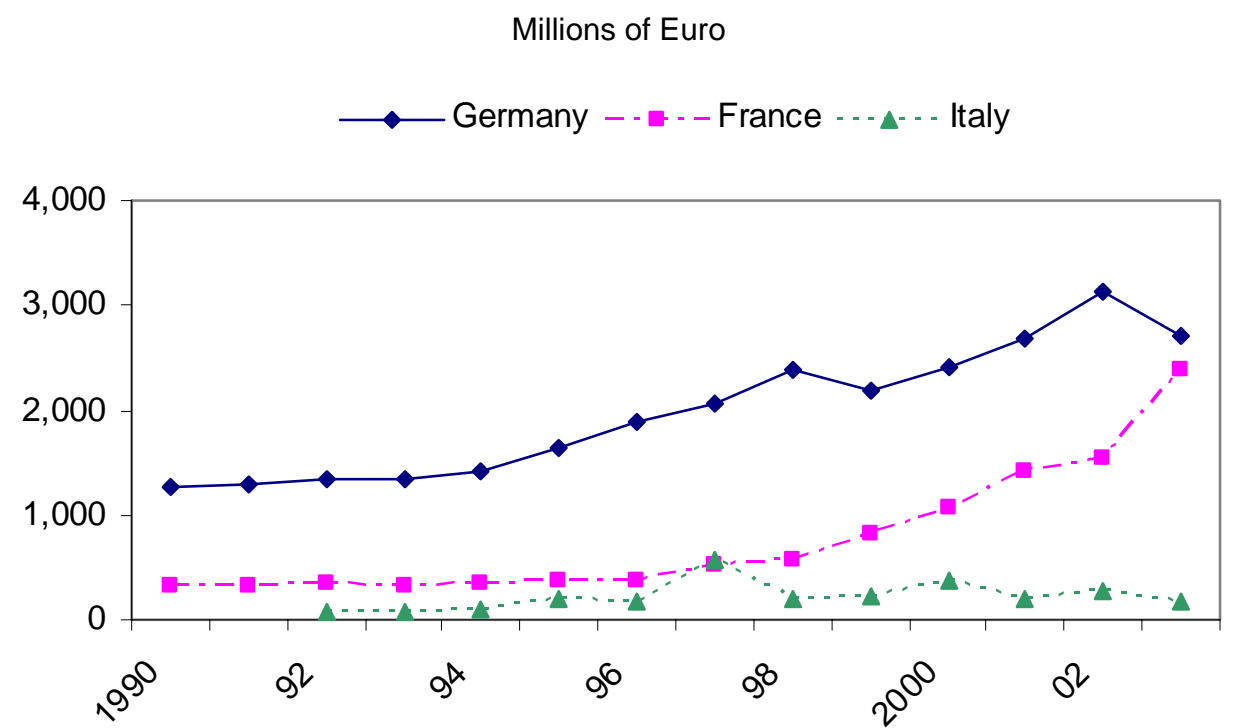

Source: OECD Technology Balance of Payments database. 
Much international licensing reflects transactions among affiliated businesses. In Japan, for example, transactions among affiliated firms accounted for approximately $60 \%$ of international royalty receipts and 14\% of royalty payments in 2002 (Figure 4). If business transactions within affiliated firms are excluded, Japan's technology licensing trade surplus (of JPY 130 billion) becomes a deficit of JPY 45 billion (JPO, 2004). Nevertheless, there are further indications that the share of transactions among unaffiliated firms is growing. In the United States, the share of transactions among unaffiliated firms in the international trade balance of intellectual property (royalties and fees) almost doubled from about 20\% in 1996 to more than $40 \%$ in $2001 .^{20}$ The share of German trade income from international intellectual property transactions with unaffiliated foreign firms doubled from about 5\% in 2002 to 10\% in 2003 (Wurzer, 2005).

Figure 4. International balance of payments for patent licences in Japan, total and within group, FY2002

Billions of Yen

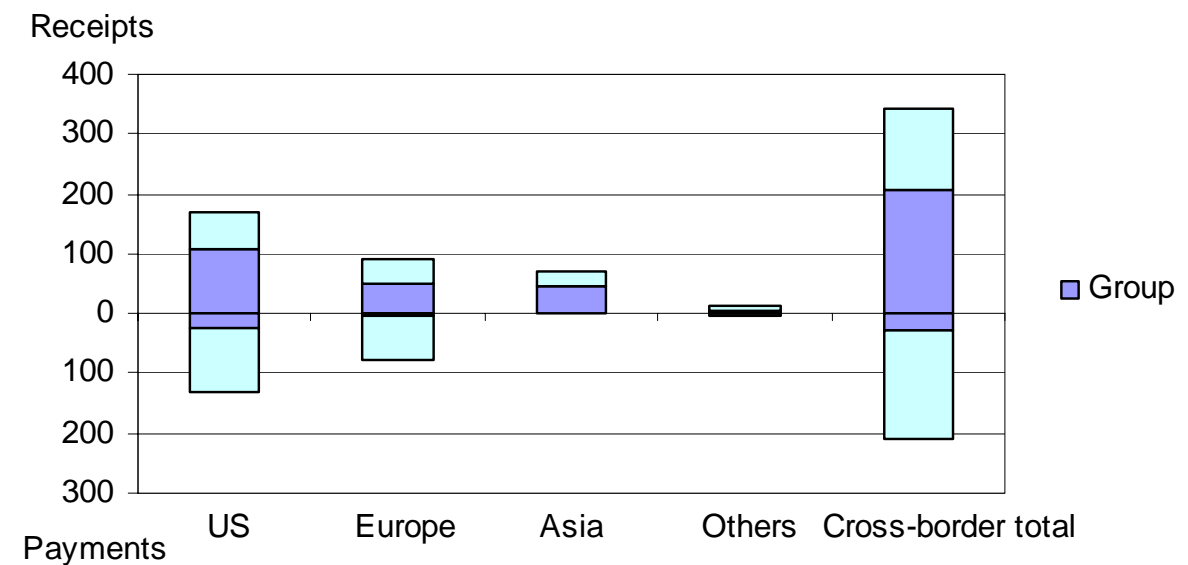

Note: Data are estimated based on responses from a sample of firms.

Source: JPO, 2004.

Public policy plays a role in international technology transfers. The strength of IPR regimes affects international transfers of technology between parents and their affiliates. A recent study found that US multinational enterprises respond to changes in foreign IPR systems (changes that strengthen IPR in foreign countries) by increasing technology transfers to those countries (Branstetter et al., 2004). ${ }^{21}$ Affiliates also respond to increasing technology transfer by increasing their R\&D expenditure to modify their parent firm's technology to meet local market needs. Similarly, an examination of licensing transactions between the late 1980s and early 2000s shows that in general strong IPR regimes provide incentives for international licensing activities, such as joint ventures and strategic alliances, between firms in developed countries (licensors) and firms in developing countries (licensees). The correlation between

The royalties and licence fees accounts cover transactions with non-residents that involve patented and unpatented techniques, processes, formulas, and other intangible proprietary rights used in the production of goods; transactions involving trademarks, copyrights, franchises, broadcast rights, and other intangible rights; and the rights to distribute, use, and reproduce general-use computer software. See US Bureau of Economic Analysis (2002), Survey of Current Business at www.bea.gov/bea/ARTICLES/2002/100ctober/1002InServ.pdf. IPR reform. 
the degree of strengthening of patent rights and the level of attractiveness for licensing appears to vary from one industry to another (Park and Lippoldt, 2004). ${ }^{22}$

\section{Exploiting IP to access financial markets}

Increasingly, firms are exploiting their patents as a means of tapping into external sources of financing. Patents can play a role in enabling firms to attract venture capital investments, and they are also being used as assets for more traditional financial markets via bank loans and securities markets. Some banks are beginning to accept patents as collateral for bank loans and to develop IP-backed securities that patent holders can use to access financing. Such approaches are used by large and small firms, but may have particular importance for smaller firms that often lack other tangible assets with which to secure (or attract) outside financing. For them, ownership of a strong IP portfolio can signal to investors that the firm has a technological advantage over its competitors - one that it can protect via patent law.

\section{IP as collateral for bank loans}

Greater attention is being paid in OECD countries to the use of IP as collateral for bank loans. The Development Bank of Japan, for example, a government-related financial institution, implemented a loan system in 1995 that allows the use of patents and patent applications, as well as copyrights of computer programmes and contents, as collateral. Since then, the Bank has granted more than 250 loans to venture firms, with the Bank assessing the present value of the cash flows to be generated by the IP. ${ }^{23}$ It is reported that the Bank of Tokyo-Mitsubishi plans to take an Intellectual Property Insurance ${ }^{24}$ provided by the Nippon Export and Investment Insurance, an independent administrative institution, as collateral in July 2005. In Germany, the Landesbank Rheinland-Pfalz (part of L-Bank Baden-Württemberg) has accepted technical documentation of research projects as (additional) collateral for the financing of development projects of mid-size companies; in the last four years about 40 transactions with a volume of EUR 140 million were realised. ${ }^{25}$ Furthermore, Germany's Federal Financial Supervisory Authority (BaFin) recently offered banks the possibility of accepting patents as a sole security for bank lending.

Use of IP as collateral for bank loans remains limited, largely because of limitations in valuation. A survey of about 50 European commercial banks found that none of them routinely accepts intangible assets as collateral for loans to new technology-based firms. ${ }^{26}$ Commercial banks reported that: i) protection of IP is more important as part of the overall assessment of the risk of a loan rather than as collateral itself; ii) the value of the IP of new technology-based firms is limited; and iii) they are not confident in the realisation of the value of the firms' IP (EC, 2000). ${ }^{27,28}$ The situation is similar in the United States (Washington CORE, 2002). In Japan, financial institutions other than those mentioned above have been reluctant to adopt such practices, as they consider the cost of IP-collateral valuation high and the resulting

\footnotetext{
22 For example, in the biotechnology industry, the higher the degree of patent reforms, the greater the positive effect on licensing deals, while in the communication industry, low and high degrees of patent reform have a positive effect rather than a medium degree of patent reform.

For further information on this programme, see www.dbj.go.jp/japanese/venture/venture_intellectual.html (Japanese).

Intellectual Property License Insurance covers losses from inability to collect licence payment such as royalties due to: i) political risk such as wars or ii) bankruptcy or delay of payment by a business counterpart when a Japanese company offers patent, know-how, copyright, etc. abroad. See http://nexi.go.jp/e/ps/index_frame.html.

The Bank reports high interest for this form of debt financing. See www.lrp.de/fs_m52a.html (German). Basic information on the Bank is available in English and Japanese at www.lrp.de.

New technology-based firms are typically defined as firms that are less than 25 years old, independent of larger firms, and established to exploit inventions or innovation, etc. (EC, 2000).

Lack of enthusiasm among financing institutions for IP-based funding was also apparent in the EPO public hearings on Basel II and Patents, 4 November 2004.

Although banks in the United States take out an "all asset lien" which normally includes IP, they are less concerned with securing the assets of individuals (EC, 2000).
} 
values of limited credibility, signalling the need for improved valuation techniques (JPAA, 2002). Some German banks have started to use newly developed methods to value patents in a systematic and transparent way, but at present there seem to be only few service providers available for valuation.

\section{IP-backed securitisation}

Some steps have also been taken to access financial markets through the use of IP-backed securities. IP-backed securitisation consists of the transfer of IP by an owner for securitisation and the receipt of capital from investors in the form of a lump sum payment. Typically royalty streams from the IP serve as capital for investors.

IP-backed securitisation is making some headway in the music industry (based on copyrighted music) and pharmaceuticals. In 1997, musician David Bowie financed USD 55 million by securitisation of future royalty streams resulting from his 25 albums. ${ }^{29}$ In 2000, Royalty Pharma arranged the securitisation of the patent for the HIV-drug Zerit, property of Yale University, but the deal defaulted due to low sales. ${ }^{30}$ Recognising the risks of securitisation of a single patent, Royalty Pharma subsequently securitised a set of 13 patents to better diversify its holdings and mitigate associated risks (Hillery, 2004). In Japan, a demonstration experiment was completed under the leadership of the study group for securitisation of patents in the Japanese Ministry of Economy, Trade and Industry (METI) to identify and address issues related to patent securitisation in 2003. ${ }^{31}$ Following the lesson from the securitisation, a revised Trust Business Law has been in force since December 2004 which abolishes the limitation of eligible property in trust business - that is, intellectual property becomes eligible property and is expected to diversify financing methods.

IP-backed securitisation remains a small portion of the total market for asset-backed securitisation in terms of total investment and number of deals completed. Several factors account for its limited use, including piracy risks, concerns over litigation, potential changes in legislation and technological obsolescence. With drug patents, additional concerns relate to possible withdrawal of patented drugs from the market. Given such concerns, IP-backed securitisation may require more substantial due diligence than conventional asset-backed securitisation and consequently may require larger transaction scales to be successfully accomplished (Harris Nesbitt, 2004).

\section{Venture capital financing}

IP can also play a role in enabling small start-up firms to attract venture capital. Ownership of a patent can demonstrate to potential investors that a small firm has a novel invention with which it may be able to differentiate its products or services from those of its competitors, as well as the legal means to prevent competitors from implementing their invention in the market place (Box 3). Research indicates that highvalue patents are among the most important factors (along with good management) that venture capitalists consider in their investment decisions (Rivette and Kline, 2000; OECD, 2004b) ${ }^{32}$ and that managers of new

\footnotetext{
29 In March 2004, the bond was downgraded from A3 to Baa3 due to the downturn in sales of recorded music. See http://launch.yahoo.com/read/news/12174412.

30 The patent was licensed to Bristol-Myers Squibb; the security was issued for USD 115 million, and Yale received a lump sum of USD 100 million.

31 This is the first case of patent securitisation in Japan. The (Japanese) press release related to this activity is available at: www.c-direct.ne.jp/japanese/uj/pdf/10104815/00013128.pdf.

See also “Intellectual Property - The Basis for Venture Capital Investments" at:
}


technology-based firms find patents a crucial factor in their success in raising funds and in competing against larger firms. ${ }^{33}$

For the most part, venture capitalists value patents not as individual assets, but in the context of an evaluation of a target firm as a whole. The role of patents varies by investment stages (Köllner, 2005):

- In the pre-investment phase, the availability of a patent may help secure the investment by increasing the visibility of the competitive advantages on which the company is bidding. They might also be seen as a liquidation benefit for the shareholders, given that the key patents may still be sold or redistributed if the company does not succeed.

- During the holding period, good patents can effectively make the difference in increasing the turnover of a growing company, and good patent management can be particularly useful to generate additional returns. During this period, patents can be used to: $i$ ) prevent competitors from entering the market; ii) protect the company's competitive advantage; iii) establish strategic partnerships; iv) serve as a bargaining chip in negotiations; and $v$ ) generate revenues or important relationships via licensing.

- At the exit phase, the visibility of patents may be useful to the venture capitalist when negotiating a merger or acquisition or preparing an initial public offering. Even in the event of failure or low turnover of the venture capital-backed company, a good patent may be redistributed or resold in the liquidation.

In general, the valuation of patents in such circumstances is based on a qualitative assessment of the contribution of a patent or patent portfolio to the value of a firm. More quantitative financial valuation is needed when patents alone are sold, but this is often conducted with the assistance of specialised intermediaries.

\section{Box 3. Patents and the value of firms}

Intellectual assets, including patents, appear to make a significant contribution to the market value of firms. Studies show, for example, that tangible assets accounted for only about $25 \%$ of the market value of US firms in 2002, suggesting that intangible assets (of which intellectual property is a part) accounted for the remaining 75\% (Kaplan and Norton, 2004). This figure is considerably higher than the $40 \%$ of market value that was accounted for by intangibles in 1982. In addition, Hall et al. (2000) showed that firms with highly cited patents (more than 20 citations per patent) showed a $50 \%$ increase in market value relative to firms with the same level of R\&D and patent stocks, but with a median level of citation intensity. ${ }^{34}$

The significance of IP and other intangibles can complicate the due diligence process that is conducted as part of investment decisions. A fundamental goal of due diligence is to reveal the problems associated with transactions and secure them. Necessary procedures for addressing IP elements in due diligence vary from deal to deal, but include the tasks listed below (Hildebrand and Klosek, 2004). While they appear fairly basic, effective execution can be difficult and without it unexpected difficulties and costs can arise after a deal is closed.

- $\quad$ Identify and locate all the IP of the target firm including patents, inventions, copyrights and trademarks.

- $\quad$ Ascertain the nature and scope of IP of the target firm, including whether it is owned outright or licensed.

- $\quad$ Evaluate the validity of the IP of the target firm in order to confirm that business can continue without problems.

- $\quad$ Evaluate the potential risks of infringement, including infringement of a third party's rights by the target firm and valid claims of infringement against third parties.

- $\quad$ Analyse any grants of IP made by the target firm, including licences, distribution agreements and resale agreements.

\footnotetext{
33 See case studies of WIPO at www.wipo.int/sme/en/case_studies/fk_biotec.htm and www.wipo.int/sme/en/case_studies/eat_set.htm.

A citation analysis for a particular patent may be useful for finding possible licensees and monitoring patent infringement since a party who cites the patent builds its inventions on it and is probably operating in the same field.
} 


\section{Valuing patents}

The expanding use of IP creates new challenges for patent valuation. Not only do patents need to be valued for use in a broader set of transactions - from decisions whether to file or renew a patent to negotiations over licensing fees to use as collateral for a bank loan - but valuations are conducted by a broader set of stakeholders. Patent holders, inventors, banks, financial analysts, and venture capitalists are all involved in valuing patents and other IP. The need for monetary valuations of patents becomes particularly relevant when they are used as financing tools by patent holders and as investment assets by financial institutions and venture capitalists (Otsuyama, 2003). Financial analysts and investors increasingly recognise IP as a key element in the value of a firm and as an indicator of its technological capabilities.

Experience suggests that limitations in patent valuation can impede the development of technology markets and the use of patents to access financial markets. As noted above, the lack of reliable methods for valuing patents has dissuaded many banks from offering loans with IP as collateral. A 2003 survey by the Japan Institute of Invention and Innovation (JIII) found that difficulty with the validity of patent valuations was the primary impediment to successful licensing negotiations (it was identified by $67.3 \%$ of respondents). Many of the other impediments, such as shortages of information about possible licensees (28.1\%) and lack of qualified technology licensing personnel (18\%), can be ameliorated by employing various types of intermediaries, but difficulties related to patent valuation will continue to arise (JIII, 2003). Another licensing survey of members of the Licensing Executives Society International (LESI) from the United States and Canada ${ }^{35}$ found similar results. The inability to reach mutually acceptable financial terms was the most frequently reported reason for not concluding successful licensing agreements (26\% of respondents for outward licensing, and 32\% for inward licensing), although difficulty agreeing on nonfinancial terms of licensing agreements ranked a close second $(23 \%$ for outward licenses, and $17 \%$ for inward licenses) (Razgaitis, 2004).

\section{Accounting for diversity}

While patent valuation is a priority issue for facilitating their exploitation, systematic IP valuation does not appear to be pervasive in OECD countries. A recent survey of European firms reveals that only $12 \%$ of respondents had employed a third party to conduct a patent valuation, despite the view that third parties may be in a better position to conduct a more authoritative, objective assessment that draws upon a broader set of experiences (DLA, 2004). Interestingly, the survey found the highest likelihood of valuation in Italy and Spain (46\% of responding firms) followed by the BeNeLux countries (42\%), United Kingdom (40\%), Scandinavia (36\%), Germany (32\%) and France (32\%). In Japan, about 50\% of the entities holding patents were found to evaluate their patent portfolio (JIII, 2003).

Several factors preclude more widespread valuation. First, when firms employ patents as a defensive tool, they have limited incentive to conduct a patent valuation, and they tend not to recognise patents as a financial asset in this situation. Second, there is a fundamental question whether or not patents can be valued in a reliable way using existing tools. Third, their value may be highly context dependent, varying according to different expectations about markets for products or services that make use of the patented invention and on the complementary assets that a firm has in place to successfully implement and commercialise the invention (these complementary assets may include other patents). The $2003 \mathrm{JIII}$ survey revealed the relative importance of various difficulties firms face in valuing patents. The valuation of present and future marketability of the products which employ the subject patented technology was seen as the most difficult issue (reported by $71 \%$ of respondents) followed by valuation of the contribution of the patented invention to products (67\%) and choice of the best method for conducting the valuation (42\%).

35 Information on Licensing Executives Society International (LESI) is available at www.lesi.org/. 
Respondents also suggested that the data limitations impede valuation. Data are needed on market size, projected sales and profits for some valuation approaches (JIII, 2003).

The challenge of valuing patents and patent portfolios is made extremely difficult due to their wide variety. While econometric studies indicate that patent protection increases the value of an invention by about $47 \%$ on average (a patent premium), significant variation exists across industries and across inventions (Arora, 2005). ${ }^{36}$ One estimate of the private value of patents using patent renewal data of United Kingdom, France and Germany (Schankerman and Pakes, 1986) found that the distributions were sharply skewed in all three countries and that economic value tends to be concentrated in a small number of patents (the implication is that most patents have little economic value). Further sectoral analysis (Schankerman, 1998) in four technology areas - pharmaceutical, chemical, mechanical, and electronics sector - using French patent renewal data showed similar skews across the industries, with the top $1 \%$ of patents accounting for $12 \%$ and $14 \%$ of the total value of patents in the pharmaceuticals and chemicals industries, respectively, and $21 \%$ and $24 \%$ for mechanical and electronics industries. Mean values of the patents were found to vary across the industries, with patents in electronics being the most valuable, followed by those in mechanicals, chemicals and pharmaceuticals, in that order. Another study (Harhoff et al., 2003) that asked German patent holders the minimum price for which they would have sold their patents, again showed skewed distributions, with most patents showing low monetary value and a small number of highvalue patents accounting for most of the total value.

Recent research also provides insight into the value of licensed patents. Two European surveys (EPO and PatVal) used different approaches, but found similar results regarding the distribution of patent values. Distributions ranged from zero to more than EUR 300 million, with the median value of licensed patents being estimated at about EUR 760000 in the PatVal survey and EUR 500000 in the EPO survey. The median value of all patents (licensed and unlicensed) in the PatVal survey was about EUR $475000 .{ }^{37}$ Work in Japan shows a difference in the value of licensed patents over time. The value of inward-licensed patents remained around JPY 30 to 40 million, but the value of outward-licensed patents increased from about JPY 40 million in 1999 to JPY 80 million in 2002 (Motohashi, 2005). A study of US patents also found that the average present value of a traded patent one year after grant was USD 130155 , whereas it was USD 42426 for non-traded patents (Serrano, 2005). The study also found that patents that had previously been traded were more likely to be renewed than other patents - and more likely to be traded or sold again. Patents that received more citations (suggesting quality) were also more likely to be traded. ${ }^{38}$ The study also showed that the value of a patent declines with its age. The estimated mean value of a patent one year after grant was USD 57 900, with those in the 99.8 percentile having a value of USD 1185 477. Patents that are four years old had a mean value of USD 43350 , even though those in the 99.8 percentile retained a high value of USD 1226341.

\section{Techniques for assessing patent value}

A number of different approaches have been proposed by experts to value patents and several have been put into practice. Methods used for business purposes can be generally divided into two groups, qualitative and quantitative valuation methods.

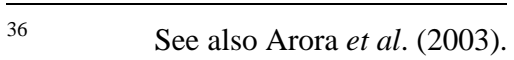

The two surveys are the EPO survey of patent holders (conducted in 2004) and the PatVal survey, which reviewed about 9000 patents in France, Germany, Italy, the Netherlands, Spain and the United Kingdom during 1993-1997. The EPO survey calculated the value of licensed patents from the average royalties received by a patent holder (firm) divided by the number of licensed patents. The PatVal survey asked for the minimum price at which the applicants would sell the patent if asked.

A patent with only 1 citation after 8 years was found to have an estimated probability of being traded of 0.0177 ; patents with 60 citations had a probability of being traded of 0.038 ; those with 100 citations, a probability of 0.063 .
} 


\section{Qualitative patent valuation methods}

Qualitative valuation methods attempt rating and scoring patents based on factors such as the strength and breadth of patent rights and their legal certainty. These methods have often been used for the purpose of internal patent management, due to its relative simplicity compared to quantitative valuation methods. In addition, some service providers offer valuation services, and some national patent offices, such as the Japan Patent Office (JPO) and the Danish Patent and Trademark Office (DKPTO) propose qualitative valuation models within their countries. ${ }^{39}$

Some examples of qualitative valuation methods developed in the private sector include the valuation tool called 'PRISM' developed by QED Intellectual Property. This tool classifies patents into four basic management models, namely: i) monopoly (patents for internal exploitation with high value); ii) defensive (internal exploitation, low value); iii) license (external exploitation, high value); and iv) joint venture (external exploitation, low value). Classification is determined by a multiple choice questionnaire inquiring about patent coverage, defensibility, profitability, revenue growth, patent attributes, industry adoption, competitive position and company capability for persons inside firms (IPA, 2004). Another example is the valuation tool developed by Nihon IR based on the valuation method built by the JPO (JIII, 2003).

In 2000, the JPO issued "Patent Evaluation Indexes for Technology Transfer," an initial evaluation tool for measuring the potential for technology transfer of patents from a large patent portfolio to respond to the request for the creation of a standard patent valuation method utilised for technology transfer, of which number is small compared to the United States and Europe due to, in part, limited number of technology licensing offices and consultants to promote business and activate industry (JPO, 2000). The model provides an evaluation of the following three specific aspects of IP (rights, transferability and business potential), as well as a comprehensive evaluation that weighs these factors according to the purpose of the evaluation.

- Evaluation of rights: status of patent application, remaining period of rights, characteristics of the invention (basic technology, minor improvement, etc.), strength of the rights, possibility of a dispute with third parties, technological superiority compared to substitute technology, level of technological completion of the invention (product, prototype, idea, etc.).

- Evaluation of transferability: necessity for additional development for commercialisation, technical support at the time of technology transfer, licence-constrained condition, obligation or co-operation of right-holder in response to infringement, etc.

- Evaluation of business potential: impediment (approval from a related authority, etc.), contribution of the patent to the business, probability of emergence of replacement technology, business size, etc.

An assessment of the tool indicated that while all three specific aspects are related to actual licensing behaviour, only the business potential evaluation is statistically significant (JIII, 2004). ${ }^{40}$ Further study is underway at the Industrial Structure Council in Japan to establish valuation methods for intellectual property, including patents, trademarks and copyrights. the DKPTO. 


\section{Quantitative patent valuation methods}

Quantitative valuation methods attempt to calculate the monetary value of the patents, including three major approaches: the cost approach, market approach and income approach (Smith and Parr, 2000), each of which is also used to value fixed assets and assets relevant to M\&A and specific projects. An emerging quantitative approach uses option pricing theory to value patents.

The cost approach is based on the cost of obtaining a patented invention by either internal development or external acquisition. This approach relies on calculations of the reproduction and the replacement cost of the patented invention: $i$ ) the cost of the reproduction is the cost of constructing the exact replica of the patented invention subject to valuation; and ii) the cost of replacement is the cost to obtain an invention with the equivalent utility to the patented invention subject to valuation. A patented invention with equivalent utility would be an invention that performs the same functions but may accomplish the required tasks in a different way (Smith and Parr, 2000). Despite its large potential for application in other settings, the cost approach is not widely used in the context of patent valuation because it does not reflect the future economic value of the valued patents. This approach may nevertheless be helpful in accounting systems, which are based on historical costs and where dictated by taxation methods (Pitkethly, 2002) or a as a supplement to the income approach (WIPO, 2003).

The market approach uses comparable patent transactions in the market as a basis to obtain the value of the patent subject to valuation. However, the low number of exchanges and the lack of transparency about their characteristics make this approach less reliable and useful than others. The market approach faces other difficult challenges such as the need to make adjustments for comparability when the difference between the subject patent and the comparable patent is not negligible (Smith and Parr, 2000). Correlation between some indicators such as citations and value of patent is empirically proven, combination of market approach and these indicators in calculations is another way for valuation of patents with advantages such as: $i)$ objective fair market value due to realised market transactions; ii) consistency and efficiency due to objective and automated data selection from public databases; and iii) efficiency for large patent portfolios, also with disadvantages such as: i) potential of underestimation of recent patents and patent applications; and ii) statistical uncertainty for valuation of a single patent (Zieger and Scheffer, 2005). ${ }^{41}$ Some proprietary services collect transaction information such as royalty rates and construct their own databases to provide comparable transaction information, but they are still limited. If the market for patents becomes more active and transaction information becomes more publicly available this approach has the potential to be used widely. For example, if firms increase their voluntary disclosures or if regulation changes to foster disclosure of patent transactions.

The income approach attempts to calculate the present value of the projected future income flow arising from the subject patent during its economic life. The discounted cash flow method allows an estimated future income flow to be converted to a present value by discounting future income estimates flow with an appropriately selected discount rate. One of the most difficult challenges in this approach is how to set a discount rate. Factors affecting the discount rate include inflation, liquidity, real interest and risk premium (Smith and Parr, 2000). It is also important to take into account that when the direct income stream from the subject patent is not available, it is required to isolate its value from the aggregated income stream of the projects (Otsuyama, 2003).

Different approaches have strengths and weaknesses and fit different circumstances. Table 4 shows a summary of advantages, disadvantages and typical uses of the three major approaches.

\footnotetext{
$41 \quad$ See, also Scheffer et al. (2005).
} 
Table 4. Comparison of the three main quantitative patent valuation approaches

\begin{tabular}{|c|c|c|c|}
\hline & $\begin{array}{c}\text { Cost } \\
\text { approach }\end{array}$ & $\begin{array}{l}\text { Income } \\
\text { approach }\end{array}$ & $\begin{array}{c}\text { Market } \\
\text { approach }\end{array}$ \\
\hline Advantages & $\begin{array}{l}\text { Objective and consistent. } \\
\text { Reliability of historic cost } \\
\text { data. } \\
\text { If a recent acquisition cost } \\
\text { of patent exists it is a } \\
\text { reliable indicator of value. }\end{array}$ & $\begin{array}{l}\text { Theoretically superior to other } \\
\text { approaches as focused on future } \\
\text { earnings or cash flow. } \\
\text { Consistency can be achieved } \\
\text { facilitating comparison across a } \\
\text { patent portfolio. } \\
\text { Widely accepted and concepts } \\
\text { widely understood. }\end{array}$ & $\begin{array}{l}\text { Practical approach which } \\
\text { makes use of prices actually } \\
\text { paid for comparable assets. } \\
\text { Variety of market-based } \\
\text { approaches such as } \\
\text { comparable companies, } \\
\text { comparable transactions or a } \\
\text { premium price-earnings- } \\
\text { multiple approach allows } \\
\text { comparison. }\end{array}$ \\
\hline Disadvantages & $\begin{array}{l}\text { No correlation between } \\
\text { expenditure on an asset } \\
\text { and its value. } \\
\text { Difficult to distinguish } \\
\text { between 'normal' operating } \\
\text { expenses and patent } \\
\text { investment expenditure. } \\
\text { Subjective nature of } \\
\text { estimate of costs of } \\
\text { replacement and some } \\
\text { patents may not be } \\
\text { replaceable. }\end{array}$ & $\begin{array}{l}\text { Requires subjective cash flow } \\
\text { allocation. } \\
\text { Translation of theory into practice } \\
\text { requires assumptions which are } \\
\text { limiting. } \\
\text { Relevant information is not always } \\
\text { readily accessible from internal } \\
\text { reporting systems. }\end{array}$ & $\begin{array}{l}\text { Given the uniqueness of } \\
\text { patents, third party arm's length } \\
\text { transactions involving similar } \\
\text { patents are infrequent. } \\
\text { Transactions involving the } \\
\text { shares of companies owning } \\
\text { patents are more frequent but } \\
\text { allocating value between the } \\
\text { business and the patent is } \\
\text { difficult. }\end{array}$ \\
\hline Typical use & $\begin{array}{l}\text { Only used in limited } \\
\text { circumstances (e.g. when } \\
\text { the replacement cost can } \\
\text { be estimated with a } \\
\text { reasonable degree of } \\
\text { reliability and confidence). } \\
\text { Cost is, however, a } \\
\text { relevant benchmark where } \\
\text { a patent has recently been } \\
\text { acquired. }\end{array}$ & $\begin{array}{l}\text { Primary valuation methodology } \\
\text { and the most widely used where } \\
\text { information of an appropriate } \\
\text { quality can be obtained. } \\
\text { The limiting nature of the } \\
\text { assumptions needs to be } \\
\text { understood and where possible } \\
\text { scenario analysis should be } \\
\text { performed. }\end{array}$ & $\begin{array}{l}\text { Eextremely important indicator } \\
\text { of value, if information on } \\
\text { recent transactions involving } \\
\text { patents exists. } \\
\text { However, in practice sufficient } \\
\text { information is rarely disclosed } \\
\text { and this methodology is used } \\
\text { as a cross check on other more } \\
\text { theoretical methodologies. }\end{array}$ \\
\hline
\end{tabular}

Source: Zieger and Scheffer, 2005.

The utility of these approaches and the frequency of their use vary according to the purpose of the evaluation. According to one estimate, the cost approach is the most suitable approach for valuation for financial accounting and corporate tax purposes, the income approach is for inheritance tax purposes and for collaterals which focus on future revenue generated by the underling IP, the market approach is for valuation for internal management purposes, which often needs the monetary value of IP for resource allocation and performance evaluation (Table5). 
DSTI/DOC(2006)5

Table 5. Application of three main quantitative patent valuation approaches to different purposes

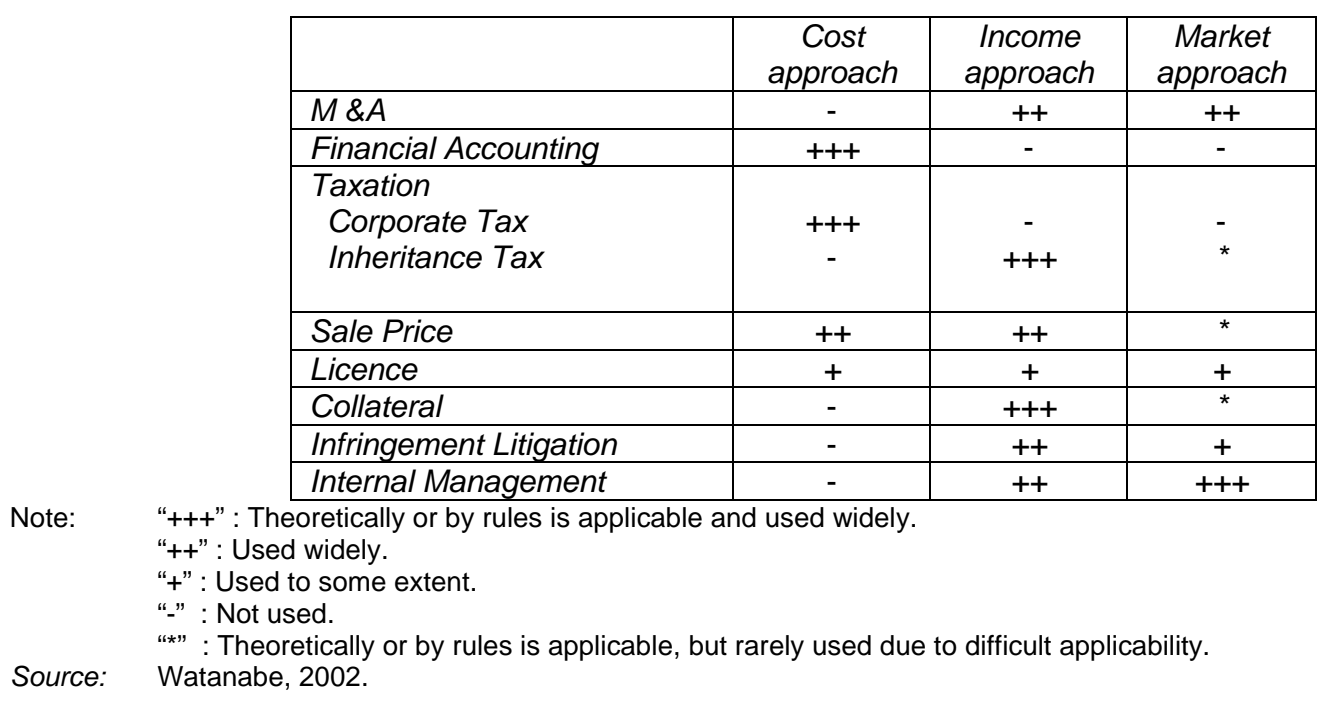

The option approach is an alternative quantitative patent valuation method which is increasingly gaining acceptance. The option pricing theory was originally developed for pricing financial options, which are defined as "a right but not an obligation, at or before some specified time, to purchase or sell an underlying asset whose price is subject to some form of random variation" (Pitkethly, 2002). The application of the concept of options is not limited today only to financial assets, as it also applies to non-financial assets, known as real options. One limitation of existing valuation methods is their difficulty in dealing with managerial flexibility, a problem that can be overcome by this approach. The real option method is able to take into account the flexibility of patent management, which can in turn be considered as a series of options. Real option models include the binomial model and the Black-Scholes option pricing model (Pitkethly, 2002). Some firms provide patent valuation services that apply the Black-Scholes equation to patents.

In practice, costs of valuation such as required money and time should also be taken into consideration. The size of patent portfolios may affect the degree of valuation (Box 4). For example, while a small patent portfolio allows in-depth annual valuation (monetary) and evaluation (non monetary valuation), simplified annual evaluation is preferable for a large patent portfolio (e.g. more than 1000 patent families and 10000 patents and patent applications) (Fröhling, 2005). 


\section{Box 4. Patent valuation at the firm level}

There are many factors to be considered in valuation in a firm, worth setting up cross-functional teams of experts from the field of IP, technology, marketing, sales and business strategy and creating common understanding among them to patent portfolio valuation and subsequent decision making such as self exploitation, sale, licence, donation to non-profit organisations and abandonment. Needless to say, firms have their own valuation practices which may vary from one to another even in the same sector and with similar sizes of patent portfolios. One example of the evaluation steps applied to value a medium sized patent portfolio would be as follows:

- $\quad$ Divide the patent portfolio into sub-portfolios or classes to make evaluation more effective.

- Make an initial classification of the importance of the patent families according to a simple HML-assessment (H=High; M=Medium; L=Low).

- Use the 80-20 rule for the evaluation and compare it with the results of HML-assessment. ${ }^{42}$

- Save cost by making a comprehensive evaluation/valuation for the decisive $20 \%$ part of the portfolio and a simpler estimation for the remaining $80 \%$ part.

It is very important to conduct plausible checks of the results of the evaluation frequently and adjust them if necessary. If a financial valuation is needed, a valuation method should be chosen based on the purpose of the valuation as the value (also score) of a patent is not static and depends completely on the purpose and encourage independent financial valuation by a second suitable valuation concept for a cross check.

Source: Fröling (2005).

\section{Econometric approaches to patent valuation}

Several attempts have been made to use econometric methods to measure the economic value of patents. They use a variety of econometric approaches based on citation data, renewal data and patent holder's estimations of value and typically aim to measure patent value in order to identify implications for public policy or enhance understanding of the innovation process rather than improve patent management and exploitation at the firm level.

- Citation data. Citation-based analysis aims to measure the value of a patent by the number of times it is cited by other patents (forward citations) or by the number of other patents it refers to (backward citations). Such information can then be used to measure effects on firm performance or value.

- Renewal data. An alternative approach estimates patent value via renewal data. This approach relies on the fact that patent systems require payment of renewal fees over time (often steeply increasing), and assumes that patent holders renew patents only when they are economically valuable. An advantage of this approach, compared to those using stock market valuations as a proxy of patent value, is that it reflects the actions and valuations of the patent holders themselves, who may be better able to estimate the economic value of the patent. The disadvantages include the fact that it is useful only for valuing patents retrospectively and usually in aggregation (Pitkethly, 2002).

- $\quad$ Patent holders estimation. Patent value can also be estimated by patent holders, using more subjective approaches. This approach typically asks patent holders for the estimated value of their patents for licensing or sale. 


\section{Encouraging valuation and exploitation: the role of public institutions}

Various efforts have been made by national and regional governments and international organisations to foster and promote the valuation and exploitation of patents and to encourage firms to make better use of patents for improving firm competitiveness and national economic performance. These public efforts recognise that developing an intellectual property rights regime that is conducive to innovation entails consideration of more than the relative strength of patent regimes and should include specific efforts to facilitate the diffusion of knowledge. Toward this end, public organisations have taken a number of steps, from improving patent quality, convening workshops and seminars, formulating guidelines and revising relevant legislation, to establishing databases of licensable patents.

National efforts in the area of IP valuation and exploitation reflect different views on the role of government in this field. The Japanese government, for example, has taken a pro-active approach to stimulating value creation from IP: its Intellectual Property Policy Outline of 2002 aims to revitalise the Japanese economy through intellectual property, and its 2006 Intellectual Property Strategic Program includes more than 370 action items, up from 270 in $2003 .{ }^{43}$ In Germany, the government plays a more limited role centred around reducing administrative burdens for the business community, improving coherence between policies at the national, European and international levels, and ensuring the efficient operation of the patenting system (Niemeier, 2005). The United States uses a more decentralised approach, with different public bodies addressing specific bottlenecks that are perceived in the system. Despite such differences, certain commonalities remain in the basic approaches taken by countries, as outlined below.

\section{Improve patent administration}

A pre-requisite for enhancing exploitation of the economic value of patents and facilitating licensing markets is an efficient and effective patenting system. High-quality patents that are enforceable in the market place, can withstand judicial challenges and are issued in a timely fashion provide innovators and investors with greater confidence in the validity - and value - of a patent. Ensuring the quality of granted patents can also help reduce the number of less valuable patents in the system. Achieving this goal implies:

- Proper screening of applications to ensure that patents meet the criteria of utility, novelty and non-obviousness that are contained in patent laws.

- Short processing times. The time span between the filing of an application and the decision to grant is a time of legal uncertainty, which deters licensing and reduces value - especially for inventions in fast-moving sectors.

- Affordable costs of patenting to ensure that filing and maintenance costs do not deter inventors from using the patent system, thereby reducing opportunities for subsequent exploitation such as licensing or attraction of external capital. This does not necessarily imply low patenting fees indeed too low a fee can encourage patenting of trivial inventions - but matching fee structures to the financial resources of different types of inventors (e.g. individuals, start-up firms, large multinationals).

- Guaranteeing clarity and transparency in the patenting process. As published documents serve as a basis for licensing deals and valuation, they should set out the essence and teaching of the invention in clear terms, as well as its assessment by the patent examiner.

Most major patent offices such as the trilateral patent offices (the EPO, the JPO and the USPTO) have processes in place to do this already, but continued efforts are valuable in responding to changing

The strategic program is annually revised. Major achievements of the strategic program include: $i$ ) Establishment of IP high court; ii) Creation of university IP headquarters; iii) Measures against counterfeits and pirated copies; iv) Increase of patent examiners; v) Promotion of media contents business; and vi) Enactment of 18 (more than 25 as of June 2006) IP-related laws (Arai, 2005). For the 2006 version, see: www.kantei.go.jp/jp/singi/titeki2/kettei/060609keikaku.pdf (Japanese). 
circumstances and improving performance. For example, the trilateral offices have been making efforts to increase the number of patent examiners as a means to speed up examination as well as improve the quality of granted patents. The number of examiners in the EPO and USPTO has reached roughly 3 500, up from about 2000 in the mid 1990s, and further increases are sought. In Japan, in addition to the recruitment of regular patent examiners, the JPO has arranged to employ specialists as fixed-term examiners, adding about 100 such examiners a year between 2004 and 2008. As of 2005, there are about 1400 patent examiners in the JPO (1 162 regular and 196 fixed-term examiners).

Additional steps can be taken as well to improve patent quality. In 2003, the UK Patent Office, for example, became the first patent office in the world to receive ISO 9001:2000 certification (International Standard for quality management system). To secure the certification of its examination process, various operations in the UKPO were subject to external assessment, including training, quality assurance procedures, ICT systems, workflow management and customer relations. Consistent with the standard and in order to assure the quality of search and examination, quality assurance reviews are conducted on samples of recent searches and examinations. The assessment criteria for the check sample include appropriateness of the search strategy, objections to applicants and timeliness. ${ }^{44}$

International co-operation can also assist in meeting these objectives. Currently the trilateral patent offices are exploring the possibility of sharing prior-art searches and examination results to speed up their examination. Comparative studies on examination practices (industrial applicability, novelty, non-obviousness, etc.) for important and emerging technologies such as biotechnology and business method-related inventions have also been conducted to improve comparability of examination practice across patent offices and improve the quality of issued patents. ${ }^{45}$ In addition to its internal quality assurance efforts, the UKPO proposed a common quality framework in 2002 for the international phase of PCT applications (i.e. for search and preliminary examination); the framework was incorporated into draft PCT guidelines in $2003 .^{46}$

\section{Improving disclosure of patent and licence information}

Public authorities also have a role to play in ensuring timely disclosure of information regarding patents and, in some cases, patent licences. Development of ICT, notably the Internet, has brought about dramatic changes in patenting procedures, including systems for disseminating patent information. Currently, many patent offices in developed countries provide free access to searchable databases with information on patent applications and grants. ${ }^{47}$ The information provided by such databases is fundamental to acquire information on state-of-the art technology, avoid unexpected infringement of third party's rights, overlapping R\&D investments and subsequent patent applications.

In addition, a number of efforts have been made to improve the provision of information about inventions that are available for licence. The European Commission created the Community Research and Development Information Service (CORDIS) which provides information about EU R\&D programmes and transferable technologies. ${ }^{48}$ Germany's Federal Ministry of Education and Research (BMBF) provides partial funding for the INSTI network, which comprises 39 private and public regional institutions for the stimulation of innovation, exploitation of inventions and promotion of the patent system in general. ${ }^{49}$

For the details, see www.patent.gov.uk/patent/quality/index.htm.

See www.jpo.go.jp/torikumi_e/kokusai_e/tws/new.htm.

See www.wipo.int/pct/reform/qualityframework/en/.

Links to Industrial Property Digital Library (IPDL) provided by several patent offices at www.ipdl.ncipi.go.jp/links_e.htm and the IPDL in Japan at www.ipdl.ncipi.go.jp/homepg_e.ipdl.

See www.cordis.lu/en/home.html.

For details, see www.insti.de (German). 


\section{DSTI/DOC(2006)5}

INSTI runs the Internet-based service called Innovation Market to link buyers and sellers of technology. ${ }^{50}$ The United States Patent and Trademark Office (USPTO) publishes an official gazette which includes information on licensable patents; the patent office expects it is used more by SMEs than large firms. ${ }^{51}$

Taking over from the JPO in 2001, Japan's National Center for Industrial Property Information and Training (NCIPI), an independent administrative institution, has been in charge of a licensing promotion programme. The programme includes several elements, such as the creation of a patent licensing database. The patent licensing database, accessible through the Internet free of charge, lists licensable patents from firms, PROs such as universities, and other inventors. As of March 2006, more than 58000 licensable patents had been registered. In addition to a description of the technology, the licence information provides terms of license, applicable products, etc. ${ }^{52}$

\section{Match-making services}

Beyond providing information to markets about patents and licences, a number of governments have taken steps to more actively facilitate match-making between buyers and sellers of technology. In some cases, such programmes are embedded into outreach and education programmes. As indicated by two recent surveys, one in Japan (JIII, 2003) ${ }^{53}$ and another in the United States and Canada (Razgaitis, 2004) ${ }^{54}$, identifying potential licensees can be a major impediment to successful licensing. Government efforts in this area are varied, but aim to complement the capabilities of private-sector intermediaries, which are growing in number and scope in OECD countries (Box 5). ${ }^{55}$

The European Commission (EC), for example, established a network of 70 Innovation Relay Centres (IRCs) in 1995. Services include help in matching buyers and sellers of technology including the Internetbased system in collaboration with the CORDIS Technology Market Place and provision of advice on innovation, intellectual property, licensing and negotiation. These services are mainly targeted at technology-based SMEs. To date, the IRCs have facilitated about 1000 technology transfer agreements, including signed agreements for the sale, licensing, distribution or joint development of new technologies. ${ }^{56}$

In the United States, the National Technology Transfer Center (NTTC), established by Congress in 1989 provides access to federally funded technology and market assessment services, technology marketing and assistance in finding strategic partners. Technology such as that developed by NASA is searchable via the Internet. ${ }^{57}$ In FY 2002, 20 commercialisation deals were facilitated and about 850 people participated in training courses.

\footnotetext{
50 For details, see www.innovation-market.de (German). Furthermore the BMBF has set up a nationwide network of Inventors-Clubs for sole inventors, students, apprentices and pupils.

Access to the database, www.ryutu.ncipi.go.jp/en/db/index.html.

Respondents (695 firms, universities and TLOs) were asked impediments to successful licensing negotiations. Shortages of information about possible licensees (28.1\%) is the second major impediment following the difficulty with the validity of patent valuations (67.3\%).

Total respondents are 229. 26\% of potential licensees were identified for licensable intellectual assets. 27\% of negotiations were started after identifying the potential licensees.

Intermediaries should not be confused with so-called patent trolls that acquire unexploited patents cheaply - such as from bankrupt firms - and attempt to raise money from damage awards or licensing fees by suing or threatening other firms with infringement suits. Recent legislation introduced to the US Congress, Patent Act of 2005, contains provisions that would limit (directly or indirectly) the activities of patent trolls. See http://irc.cordis.lu/.

See www.nttc.edu/default.asp.
} 
The JPO and Japan's NCIPI, in addition to providing a database of licensable patents by NCIPI, also offer match-making services that aim to link buyers and sellers of patented inventions through mechanisms like licensing fairs and patent licensing advisors.

- $\quad$ Patent licensing fairs (JPO): The fairs provide a meeting place for technology providing and seeking parties. In FY2004, the fairs were held in 8 cities, more than 600 firms participated and more than 170000 people attended (Yonetsu, 2005).

- $\quad$ Patent licensing advisors (NCIPI): A patent licensing advisor is an expert in technology transfer. As of March 2006, more than 100 advisors were dispatched to prefectural governments and TLOs etc. Their activities include: i) collection of technological needs and licensable seeds by visiting firms and PROs; ii) matching firms; and iii) support for a contract. Their consultations and advice are free of charge. Its economic impact has been estimated at more than JPY 200 billion between 1997 and 2005; the programme is attributed with creating about 7000 technology transfer contracts during the period and more than 1000 new jobs between 1997 and $2003 .^{58}$

58 See www.ryutu.ncipi.go.jp/about/seika_i.html (Japanese) and www.ryutu.ncipi.go.jp/en/pdf/guide-e.pdf. 


\section{Box 5. IP and technology intermediaries}

Intermediaries play an important role in the valuation and exploitation of IP. As innovation processes have become more open and firms have begun to source more of their technology needs from external sources, markets for technology have expanded, and with them the role of intermediaries. Intermediaries provide value-added along four dimensions (Stern, 2005):

- Connectivity - as they have access to key gatekeepers, and have relationships with venture capitalists and SMEs. Furthermore, they tend to have cross-industry and cross-geography experience and knowledge.

- Confidentiality - as they provide a good opportunity for screening and for initial discussions. At that stage, they guarantee that the client's name and the application of a technology is protected.

- Expertise - as they have experience regarding major evaluation and communication methods as well as market knowledge. Furthermore, they have business creation (entrepreneurial) and commercialisation skills.

- External perspective - as they provide an external perspective by giving unbiased evaluations and offering critical thinking which may be absolutely essential to successfully leverage technology assets.

Intermediaries take several forms and set different customer targets (e.g. multinational enterprises, SMEs and universities) and services. They include:

- Technology licensing offices (TLOS) that deal mainly with patents arising from university and other PROs; these institutions have responsibility for identifying potential licensees and negotiating licences. ${ }^{59}$ The number of such organisations has grown as PROs have begun to more actively manage their IP, often with encouragement or support from their governments.

- Patent transaction intermediation systems, including various web-based platforms where patent holders post licensable inventions and technology seeking parties post their needs. In recent years, a number of such web sites have failed and a series of mergers and acquisitions has consolidated the number of remaining intermediaries. ${ }^{60}$

- Comprehensive service providers that assist clients in acquisition, commercialisation and investment in technologies, patent protection and assertion, with the aim to levy royalty income, as well as monitoring patent infringement. ${ }^{61}$

- Specialists in particular technology fields, such as biotechnology and ICT, that provide a range of IP services to organisations in their field of expertise. ${ }^{62}$

In general, large firms organise internally the commercialisation of core technologies related to their primary markets, but they may seek the help of intermediaries for commercialising core technologies in other markets and the commercialisation of non-core technologies. Intermediaries also provide services for SMEs which aim to find large companies for collaborative development and distribution purposes. Technology licensing by SMEs can result in strategic alliances and cross-licensing to other SMEs. For universities and research institutes, intermediaries can assist in the creation of spin-off companies as well as with the management and licensing of patents.

\section{Support for patenting and licensing in public research organisations}

Officials in most OECD governments recognise the need to support patenting and licensing efforts within public research organisations - both universities and government research laboratories. Such efforts are aimed at increasing the economic and social benefits from public investments in R\&D by facilitating the commercialisation of inventions. A first step in such efforts is to enact the legal reforms necessary to allow public research institutions to retain the rights to IP resulting from government-funded research and that, in some cases, require them to seek opportunities to commercialise inventions. In the United States,

$59 \quad$ For more information on PROs patenting and licensing and technology licensing offices, see OECD (2003).

See, for example, Yet2.com, www.yet2.com/app/about/about/aboutus. In 2002, Scipher plc, a parent of QED Intellectual Property Ltd., acquired Yet2.com. QED was acquired by Innovation Development Ltd. in 2004. See www.qed-p.com/pr/2003_jan_15.htm, www.qed-ip.com/pr/2004_May_14.htm. 
the Bayh-Dole Act of 1980 allows small business firms and non-profit organisations including universities to elect to retain title to inventions derived from federally funded R\&D. In Japan, two laws were enacted in the late 1990s to support the exploitation of patents in universities. One is to support the establishment of technology licensing offices; the second is the Japanese version of the Bayh-Dole Act. Many other OECD countries have taken similar steps. ${ }^{63}$

Most OECD countries have recognised that promotion of patenting and patent exploitation among public research institutions requires specific support and incentives even after an accommodating regulatory framework has been put in place. There is much to be done to develop the human resources needed for effective IP management and the financial and management systems to support it. According to leading technology transfer officials, effective technology licensing offices require staff that combine broad business experience with technological depth; they often lack financial resources to maintain operations - which can lead them to focus on generating revenue from licensing, instead of focusing on transfer of technology. They also need ways to solicit advice from IP and legal experts and a clear mission that can be used to appropriately assess performance (Secher, 2005). ${ }^{64}$

Japan's regulatory regime provides public research organisations and technology licensing offices with an exemption or reduction of $50 \%$ of the annual fees for patents and the fees to request examinations. In addition, since 2002, the JPO has dispatched IP managers in private sectors as IP Management Advisors to universities to establish IP management units. Regional Bureaus of Economy, Trade and Industry organise seminars for researchers in PROs to explain how to draw up the patent specifications and the significance of social exploitation of research results via patenting. As of March 2005, these efforts had been credited with producing a six-fold increase in the number of patent applications from PROs since 1999; a seven-fold increase in universities' royalty income; and 1100 new venture firms spinning out of universities (Arai, 2005). ${ }^{65}$

In Europe, national governments have also taken steps to support patent management in PROs. The BMBF in Germany, for example, provides support to universities for the establishment of regional patent exploitation agencies, such as the Patent Centre for German Research of the Fraunhofer Gesellschaft which manages inventions from universities. ${ }^{66}$ In Finland, Tekes (the National Research Agency) periodically provides specific training courses for researchers to enhance the awareness of IP, including how to patent. These efforts seem to have contributed to the recent increasing number of patent application from academic and SMEs' projects since 2001. In addition, Tekes covers the costs related to patenting from academic and SMEs' research projects (Heikinheimo, 2005). ${ }^{67}$

In the United Kingdom, the Lambert Review, an independent review of business-university collaboration, concluded in 2003 that technology transfers via business-university collaborations needed to be improved in order to enhance the UK's innovation performance. The review also noted that the major practical difficulties encountered in setting up contractual agreements often lead to the abandonment of collaboration projects. In order to improve such technology transfers, the UKPO launched a programme to produce a set of five model contracts for research collaboration, to be used on a voluntary basis by industry

63 See OECD (2003) and OECD (2004c) for a review of these efforts.

According to licensing experts, the number of spin-out firms from a public sector technology transfer office does not constitute an adequate performance measurement. Rather, the assessment has to be linked to the mission of the office, which may be oriented more towards income generation or more towards the transfer and diffusion of new technological knowledge (Secher, 2005).

According to the 2006 Japanese IP Strategic Program, the number of venture firms spinning out of university has reached about 1500 by the end of March 2006.

66 This agency is also involved in the exploitation of inventions made by SMEs and individual inventors.

Tekes' primary mission is to sponsor research projects performed by universities, SMEs and large firms to promote the competitiveness of Finnish industry and service sectors, by sustaining the development of high value technological applications (Heikinheimo, 2005). 
and universities to facilitate business-university negotiations. This so-called Lambert Model Toolkit addresses key issues related to IP ownership, use of research results, the financial contribution of businesses and publication criteria for universities (Cullen, 2005). ${ }^{68}$

\section{Training, education and outreach to small firms}

Some governments in OECD countries have also initiated IP-related training and education programmes to help patent holders better recognise the value of their patents, make better use of the patent system and engage more actively in licensing activities. A number of such efforts are targeted specifically at small firms, which are perceived to have more limited understanding of the patent system and capability to engage in technology licensing. Support programmes for patenting and patent exploitation in small firms take similar forms to those of universities, such as holding seminars to foster human resources and financial support. However, in some cases, policy makers may be required to take into account their different roles in society, when they formulate the support programmes.

The BMBF in Germany has set up an SME patent action fund (KMU-Patentaktion) that offers financial support to small firms for expenses ranging from patent application to exploitation. The USPTO holds an annual independent investors conference which includes licensing and marketing experts, focusing on the needs of small entities. Assistance and education activities of the US Small Business Administration include elements related to IPR management such as how to protect inventions via the patent system (Santamauro, 2005). Under US patent law, applications and maintenance fees have also been reduced (by 50\%) for SMEs, independent inventors and non-profit organisations. ${ }^{69}$

In Japan, since 2004, a private organisation under contract to the JPO conducts prior-art searches free of charge for small firms, with the objective to assist the decision to request examination. In addition to PROs and TLOs, small firms and venture firms can also benefit from a system of reduced fees (50\%) for the annual patent fees and the fees to request examinations. Some support is also available to private sector intermediaries that aim to assist firms in the patenting and licensing process. To foster development of a more mature private-sector IP intermediary business, a nationwide directory of intermediaries has been created (66 intermediaries were registered as of August 2005), and a number of seminars have been organised to provide opportunities for intermediaries to exchange information.

Efforts are also under way at the international level. Initiatives of the Small and Medium-Sized Enterprises (SMEs) Division of the World Intellectual Property Organisation (WIPO) include organising seminars and workshops across the globe and providing web-based information (articles, case studies, etc.) for IP licensing, valuation and financing. A training manual, "Exchanging Value - Negotiating Technology Licensing Agreements," which aims to provide practical issues in the process of negotiating technology licensing agreements, was released in co-operation with the International Trade Centre (ITC) in $2005 .^{70}$

\section{Regulations and guidelines for exploitation}

To promote patent exploitation, steps have been taken to clarify regulations and guidelines that can affect firm behaviour. For example, Japan's Fair Trade Commission prepared a guideline on patent pools related to standards to clarify issues related to competition policy. ${ }^{71}$ In addition, in 2005 the New Bankruptcy Law was introduced in Japan, which strengthens the protection of IP licensees in the event that licensors face bankruptcy. At the international level, the OECD Council has adopted Guidelines for the

\footnotetext{
For further information and an Internet version of the toolkit, see: www.innovation.gov.uk/lambertagreements/. A CD-ROM version is also available from the UK PO, see: www.patent.gov.uk/about/ippd/knowledge/lambert.htm. 
Licensing of Genetic Inventions which outline principles and best practices for the licensing of genetic inventions used for purposes of human healthcare. ${ }^{72}$ At the European Union level, a new technology transfer block exemption regulation, with a safe harbour rule governing patent licensing, know-how and software copyright, entered into force in May 2004 as part of a broader set of reforms to competition law reform that are expected to reduce bureaucracy and increase legal certainty. ${ }^{73}$ As such reforms are recent, their impact on licensing practice cannot yet be determined.

\section{Financial incentives for patent licensing}

Specific mechanisms have also been introduced in some countries to provide financial incentives for patent licensing. The patent offices of Germany, France and the United Kingdom have introduced a system of licences-of-right that offer patent holders a discount on renewal fees (of around $40 \%$ to $50 \%$ ) in exchange for their agreement to offer non-exclusive licences to any party that requests one. ${ }^{74} \mathrm{~A}$ number of firms have taken advantage of licences-of-right, with large electronics firms appearing to be the most numerous users of this system. Further evaluation of this mechanism is needed to better understand its impact on licensing behaviour and the types of patents that are introduced into the system.

In addition, a number of countries use their tax systems to encourage patenting and licensing. One way to do this is by offering tax reductions on royalties generated by patent licences. In general, countries in Europe, North America and East Asia treat patent royalties similarly in their tax codes: royalties received are treated as taxable income, which is taxed at the prevailing corporate income tax rates; expenses related to patenting, purchase of patents and payment of patent royalties are deductible from taxable business income and not taxed. However, some countries provide special incentives for patenting income. The Irish government offers a full tax exemption for royalty income generated by the licensing of patents that result from R\&D conducted in Ireland. Switzerland, Hungary and Korea offer a partial deduction, typically 50\%, in income tax. France offers reductions in capital gains tax under certain conditions (Warda, 2006).

Tax codes can also promote technology transfer via the donation of patents to non-profit organisations. The US Internal Revenue Service (IRS) confirmed as long ago as 1958 that patent holders could receive tax benefits for donations of intellectual property to non-profit organisations (Layton and Bloch, 2004) ${ }^{75}$ Firms that donate patents can avoid the administrative costs associated with their maintenance and renewal, as well as costs of internal management, but the aim of donation provisions in tax codes is to generate societal benefits by giving an unexploited invention a chance to be further developed and put into practice by the recipient (Marcinkowski, 2000). Of course, such donations can have other benefits, too, such as

\footnotetext{
72 For further information, see: www.oecd.org/sti/biotechnology/licensing.

73 Under Article 81(3) of the EU Treaty, an anti-competitive agreement may be exempted from Article 81(1) prohibiting agreements which restrict competition. The guidelines explain agreements not covered by the safe harbor. To benefit from the exemption, it is required to be below certain market share thresholds, $20 \%$ (combined share) for licensing agreements between competitors and $30 \%$ (share of the each party) for agreements between non-competitors. Also there are provisions called "excluded restrictions" (e.g. obligation of grant-back of rights to future improvements), technology transfer agreements which contains such restrictions can not benefit from the exemption. For further information, $\quad$ press release (ref.IP/04/470) at: http://europa.eu.int/rapid/pressReleasesAction.do?reference=IP/04/470\&format=HTML\&aged=0\&language=EN\&gui Language=en.

For more information about the system in the UK, see: www.patent.gov.uk/patent/indetail/lofright.htm. The German Patent and Trade Mark Office provides a searchable database of licenses of right within the patent register at https://dpinfo.dpma.de.

75 The use of patent donations for tax deductions did not gain considerable attention until the late 1990s. In 1996, Dow Chemical donated patents to Case Western University, setting the precedent for patent donations by other large firms with significant R\&D, such as Procter \& Gamble, Boeing, Caterpillar and Eastman Chemical (Layton and Bloch, 2004).
} 
enhancing the donors' reputation as an industry leader and good corporate citizen, and establishing valuable relationships with recipients that may lead to future joint ventures.

In practice, the benefits of such donations remain unclear. Interviews with more than 80 US firms, universities, IP appraisers and the IRS confirmed only non-quantifiable benefits for donors and recipients of IP, due in part to their reluctance to provide financial information related to donated patents (Layton and Bloch, 2004). ${ }^{76}$ Moreover, scepticism has mounted about the seemingly high values assigned to the donated patents, resulting in increased scrutiny of such donations by the IRS (Layton and Bloch, 2004). While firms have always been required to retain independent appraisers to value donations, implementation of new legislative provisions would require tax deductions for patent donations to be based on the realised economic benefits derived from the donated patents. ${ }^{77}$

\section{Valuation tools}

In some countries, governments have aimed to develop analytical tools to assist firms in valuating and exploiting their patents. The idea is to promulgate use of a common set of well-defined tools that can enable patent holders to more easily and accurately value their patent holdings and provide some assurances of the validity of the valuation.

One of the most well-known efforts is that of the Danish Patent and Trademark Office (DKPTO), which released a report in 2000 on "Management and Evaluation of Patents and Trademarks." The report included two evaluation models (qualitative method) for patents and trademarks, similar to the patent evaluation indexes promulgated by the JPO (Ernst \& Young and Ementor Management Consulting, 2000). In 2001, the DKPTO released a basic model of an IP management software tool named IPscore ${ }^{\circledR}$ that assists in the evaluation and strategic management of patents and development projects. The software provides a qualitative assessment of a patented technology by evaluating five categories (legal status, technology, market conditions, finance and strategy). It also enables the calculation of quantitative financial forecasts of the value of a patented technology based on information regarding development costs, development time, market conditions and product conditions (Nielsen, 2004) ${ }^{78}$ The EPO has acquired the rights to IPscore ${ }^{\circledR}$ from the DKPTO and to make the programme available to patent offices across the member states and also to their patent libraries. The tool is intended to provide a preliminary screening of the value of a patent portfolio and provide information that can be used by patent attorneys and capital investors (Pompidou, 2005).

In Germany, to further expand the use of patents as collateral for bank loans, regional patent information centres (PIZs) are advertising valuation services that are required for patent holders who wish to take out bank loans with their patents as collateral. Several PIZs intend to enhance their patent valuation and exploitation services in the near future.

\section{Disclosure and reporting guidelines}

In a number of countries, steps have also been taken to assist firms in publicly reporting information about their intellectual assets, including their patents and other intellectual property (Box 6). The governments of Denmark, Germany and Japan, for example, have worked with industry and other relevant

\footnotetext{
$76 \quad$ Securing the financial benefits of patent donations appears to be a more serious issue for non-profit organisations than corporate donors because recipients must pay maintenance fees after receiving donated patents. For example, the University of Virginia received via donation patents valued at more than USD 7 million, but were unable to successfully commercialise them. The University eventually put them in to the public domain so as to be able to stop paying maintenance fees. See: www.m-cam.com/downloads/20030108_donation-whitepaper.pdf.

The American Job Creation Act, passed by Congress in late 2004, changes the basis of calculating the tax deduction resulting from patent donations. Under the new rule, the donor can deduct portions (10-100\%) of the income from the exploitation of underlying patents in limited subsequent years after donation (Warda, 2005).

Further information is available at: www.dkpto.dk/int/patents/ipscore.htm.
} 
stakeholders to develop guidelines for non-financial disclosures of information regarding intellectual assets:

- Intellectual Capital Statements: The New Guideline, Ministry of Science, Technology and Innovation, Denmark, 2003. ${ }^{79}$

- Intellectual Capital Statement - Made in Germany, Federal Ministry of Economics and Labour, Germany, 2004. ${ }^{80}$

- Reference Guideline for Intellectual Property Information Disclosure, 2004 and Guidelines for Disclosure of Intellectual Assets Based Management, Ministry of Economy, Trade and Industry, Japan, 2005. ${ }^{81}$

The European Union, through its MERITUM project, has supported similar efforts. ${ }^{82}$ These guidelines aim to assist firms in preparing reports with qualitative and quantitative information about their intellectual assets and the contributions of those assets to firm performance. Such information is not contained in standard financial reports. It is hoped that such disclosures will provide relevant information to managers and investors about the value of firms and improve the efficiency of financial markets.

See: www.videnskabsministeriet.dk/cgi-bin/theme-list.cgi?theme_id=100650\&_lang=uk.

See: www.bmwa.bund.de/Redaktion/Inhalte/Pdf/B/br-wissensbilanz-englische-fassung,property=pdf.pdf.

See: www.meti.go.jp/english/information/downloadfiles/cIPP0403e.pdf and www.meti.go.jp/policy/intellectual_assets/GuidelineforIAM.pdf.

For information on MERITUM, see Guidelines for Managing and Reporting on Intangibles, MERITUM, 2002. A number of firms have also experimented with approaches for reporting investments in intangibles, including patents. For example, Skandia Corp. developed a prototype intellectual capital report that received considerable attention. See www.skandia.com/en/ir/annualreports.shtml. A more complete summary of reporting initiatives is available in OECD (2004d). 
In the United States, the private-sector Financial Accounting Standards Board (FASB) has agreed that "financial reporting should provide information that is useful to present and potential investors and creditors and other users in making rational investment, credit, and similar decisions". ${ }^{83}$ Current accounting standards in most countries do not fully capture intangible assets including patents, however. In order to be reported as an asset in financial statements, an item is required to meet several criteria according to FASB rules. First, it must meet the definition of an asset and offer "probable future economic benefits obtained or controlled by a particular entity as a result of past transaction or events". ${ }^{84}$ In addition, it must satisfy three criteria namely measurability, relevance and reliability. ${ }^{85}$ In other words, an item lacking reasonably reliable measurement can not be recorded as an asset in a financial statement which leaves out most of intangible assets.

Recent developments may encourage greater reporting of intangible assets. In 2001, FASB released SFAS No.141, "Business Combinations" which requires that all business combinations be accounted for by the purchase method, recording a business combination based on values exchanged, instead of by the pooling method. This change makes it possible to provide better information about the total purchase price paid to acquire another entity. It is also required that intangible assets be reported separately from goodwill, if the assets arise from contractual or other legal rights or if they are separable from an acquired entity. ${ }^{86}$ Patents, licences and royalty agreements are listed as such intangible assets. $^{87}$ In addition, the US Sarbanes-Oxley Act of 2002, which aims to improve the accuracy and reliability of corporate disclosures, also affects reporting practices for intangible assets, through requirements to indicate important IP assets, risk factors related to IP and any material IP litigation, etc. ${ }^{88}$

\section{Conclusion}

The analyses presented in this paper suggest that firms extract value from their patents through a range of mechanisms, not only by using patent protection to establish a dominant position in the market place, but also by gaining additional revenues and access to complementary technology via licensing, by using the patents as bargaining chips in negotiations with other firms (e.g. regarding mergers and acquisitions, joint ventures and cross-licensing) and by attracting external sources of financing (e.g. from banks or venture capitalists). Improved exploitation demands better methods of valuing patents and greater efficiency in technology licensing markets.

While the main players for the development of technology markets and of valuation techniques will come from the private sector, governments efforts are also required to some extent. Those efforts vary from country to country and organisation to organisation. There is a general consensus on the need for governments to ensure the efficient operation of patent systems, as well as to provide information on patent applications and grants, and put in place regulatory environments that encourage patent management in PROs. Most governments have also taken steps to support education and training programmes for particular populations of patent holders (e.g. PROs, SMEs), and some have begun to complement or support industry efforts to develop guidelines for IP reporting and valuation. Co-operation among stakeholders and co-operation among governments can help facilitate such efforts and develop good

83 FASB(1978), Paragraph 34, SFAC No.1, Objectives of Financial Reporting by Business Enterprises.

FASB(1985), Paragraph 25, SFAC No.6, Elements of Financial Statements.

FASB (1984), SFAC No.5, Recognition and Measurements in Financial Statements of Business Enterprises.

FASB launched project on Disclosures of Intangible Assets in 2002 aiming to establish standards for improving disclosure of information about internally developed intangible assets. The project was removed from its research agenda in January 2004.

Examples of intangible assets recognised apart from goodwill include: $i$ ) trademarks, tradenames (marketing-related intangible assets); ii) customer lists (customer-related intangible assets); iii) plays, operas, ballets (artistic-related intangible assets); iv) licensing, royalty, standstill agreements (contract-based intangible assets); and $v$ ) patented technology (technology-based intangible assets). See FASB(2001), Appendix A, SFAS No.141, Business Combinations.

Sarbanes-Oxley Act of 2002, Public Law No: 107-204(2002). Additional information on its provisions is available at http://westorg.org/nl/featured_articles/IP_011304.html. 
practice. International efforts are required in many fields including collection of data related to technology markets to develop improved indicators to enable more reliable policy analysis. In this situation, international organisations are also expected to play an important role to facilitate IP as an economic asset. 


\section{REFERENCES}

Anand, B.N. and T. Khanna (2000), "The Structure of Licensing Contracts”, The Journal of Industrial Economics, 48(1), 103-135.

Arai, H. (2005), “Strategy in Japan on IP Valuation \& Exploitation”, presentation at EPO-OECD-BMWA International Conference on Intellectual Property as an Economic Asset: Key Issues in Valuation and Exploitation, 30 June-1 July 2005, Berlin, www.oecd.org/sti/ipr.

Arora, A. (2005), “Patents: Who Uses Them, for What and What Are They Worth?” presentation at EPOOECD-BMWA International Conference on Intellectual Property as an Economic Asset: Key Issues in Valuation and Exploitation, 30 June-1 July 2005, Berlin, www.oecd.org/sti/ipr.

Arora, A. and M. Ceccagnoli (2005), "Patent Protection, Complementary Assets, and Firms' Incentives for Technology Licensing”, Management Science.

Arora, A., M. Ceccagnoli and W.M. Cohen (2003), “R\&D and the Patent Premium”, NBER Working Paper 9431.

Arora, A., A. Fosfuri and A. Gambardella (2001), Markets for Technology: The Economics of Innovation and Corporate Strategy, MIT Press, Cambridge, Mass.

Baba, R. (2003), “Are Patent Strategies of Japanese Companies OK?” Introductory Chapter, in Samejima, M., ed., Patent Strategy Handbook, Chuokeizai-sha, Tokyo.

BMBF (2004), Technologie und Qualifikation für neue Märkte, www.technologische-leistungsfaehigkeit.de/de/1869.php.

Branstetter, L. G., R. Fisman and C. F. Foley (2004), "Do Stronger Intellectual Property Rights Increase International Technology Transfer? Empirical Evidence from U.S. Firm-Level Panel Data”, World Bank Research Working Paper, No 3305.

British Technology Group (BTG) (1998), IPR Benchmark Study.

Chesbrough, H. (2003), Open Innovation: The new imperative for creating and profiting from technology, Harvard Business School Press, Boston, Mass.

Cohen, W.M., A. Goto, A. Nagata, R.R. Nelson and J. P. Walsh (2002), "R\&D Spillovers, Patents and the Incentives to Innovate in Japan and the United States”, Research Policy, 31, 1349-1367.

Cullen, L. (2005), "Exploitation through Collaboration: Saving Time and Cost Negotiating IP Rights”, presentation at EPO-OECD-BMWA International Conference on Intellectual Property as an Economic Asset: Key Issues in Valuation and Exploitation, 30 June-1 July 2005, Berlin, www.oecd.org/sti/ipr.

DLA (2004), European Intellectual Property Survey. 
Ernst \& Young and Ementor Management Consulting (2000), Management and Evaluation of Patents and Trademarks, Consultants' Analysis Report for Danish Patent and Trademark Office, www.innovationskraft.dk/publications/reports/analysis_patent_trademark/management_and_evaluati on_of_patents_and_trademarks.pdf.

European Commission (EC) (2000), Funding of New Technology-Based Firms by Commercial Banks in Europe, Brussels.

European Patent Office (EPO), Japan Patent Office (JPO) and United States Patent and Trademark Office (USPTO) (2004), Trilateral Statistical Report 2003 Edition, www.jpo.go.jp/torikumi_e/kokusai_e/tws/tsr2003/ch2.pdf.

Federal Trade Commission (FTC) (2003), To Promote Innovation: The Proper Balance of Competition and Patent Law and Policy, www.ftc.gov/os/2003/10/innovationrpt.pdf.

Financial Accounting Standards Board (FASB) (1978), SFAC No.1, Objectives of Financial Reporting by Business Enterprises.

Financial Accounting Standards Board (FASB) (1984), SFAC No.5, Recognition and Measurements in Financial Statements of Business Enterprises.

Financial Accounting Standards Board (FASB) (1985), SFAC No.6, Elements of Financial Statements.

Financial Accounting Standards Board (FASB) (2001), SFAS No.141, Business Combinations.

Fröhling, W. (2005), "Practical Experiences Regarding the Evaluation of Medium-Sized Patent Portfolios”, presentation at EPO-OECD-BMWA International Conference on Intellectual Property as an Economic Asset: Key Issues in Valuation and Exploitation, 30 June-1 July 2005, Berlin, www.oecd.org/sti/ipr.

Gambardella, A. (2005), “Assessing the Market for Technology in Europe”, presentation at EPO-OECDBMWA International Conference on Intellectual Property as an Economic Asset: Key Issues in Valuation and Exploitation, 30 June-1 July 2005, Berlin, www.oecd.org/sti/ipr.

Gans, J.S. and S. Stern (2003), “The Product Market and the Market for "Ideas”: Commercialization Strategies for Technology Entrepreneurs”, Research Policy 32, 333-350.

Grindley, P. C. and D. J. Teece (1997), "Managing Intellectual Capital: Licensing and Cross-licensing in Semiconductors and Electronics”, California Management Review 39(2), 8-41.

Gu, F. and B. Lev (2004), “The Information Content of Royalty Income”, Accounting Horizons, 18(1), $1-12$.

Hall, B.H., A. Jaffe and M. Trajtenberg (2000), “Market Value and Patent Citations: A First Look”, NBER Working Paper 7741.

Hall, B. H. and R. H. Ziedonis (2001), “The Patent Paradox Revisited: An Empirical Study of Patenting in the U.S. Semiconductor Industry, 1979-1995”, RAND Journal of Economics, 32(1), 101-128.

Hansen, S., A. Brewster and J. Asher (2005), Intellectual Property in the AAAS Scientific Community: A Descriptive Analysis of the Results of a Pilot Survey on the Effects of Patenting on Science, http://sippi.aaas.org/survey/. 


\section{DSTI/DOC(2006)5}

Harhoff, D., F. M. Scherer and K. Vopel (2003), "Citations, Family Size, Opposition and the Value of Patent Rights”, Research Policy, 32, 1343-1363.

Harris Nesbitt (2004), Asset-Backed Update, www.securitization.net/pdf/secnewsletter_feb04.pdf.

Heikinheimo, R. (2005), "Valuation of Intellectual Property in Tekes Decision Making”, presentation at EPO-OECD-BMWA International Conference on Intellectual Property as an Economic Asset: Key Issues in Valuation and Exploitation, 30 June-1 July 2005, Berlin, www.oecd.org/sti/ipr.

Heller, M.A. and R.S. Eisenberg (1998), “Can Patents Deter Innovation? The Anticommons in Biomedical Research”, Science, 280, 698-701.

Hildebrand, M.J. and J. Klosek (2004), Intellectual Property Due Diligence: A Critical Prerequisite to Capital Investment.

Hillery, J.S. (2004), Securitization of Intellectual Property: Recent Trends from the United States, www.iip.or.jp/summary/pdf/WCORE2004s.pdf.

Hirosaki, B. (2005), "Intellectual Asset Strategy at NEC: Integration of Business Strategy and Open Innovation”, presentation at EPO-OECD-BMWA International Conference on Intellectual Property as an Economic Asset: Key Issues in Valuation and Exploitation, 30 June-1 July 2005, Berlin, www.oecd.org/sti/ipr.

Information-Technology Promotion Agency, Japan (IPA) (2004), Report of IPA Intellectual Property Study Group, IPA, Tokyo.

Japan Institute of Invention and Innovation (JIII) (2003), Survey on Patent Valuation System in Patent Licensing Market, JIII, Tokyo.

Japan Institute of Invention and Innovation (JIII) (2004), Survey on Verification and Evaluation of Patent Valuation System Based on Patent Licensing Contracts, JIII, Tokyo.

Japan Patent Attorneys Association (JPAA) (2002), Report of Survey of Needs for Intellectual Property Valuation, JPAA, Tokyo.

Japan Patent Office (JPO) (2000), Patent Valuation Indexes for Technology Transfer, JPO, Tokyo.

Japan Patent Office (JPO) (2002), Survey on Technology Trend of Patent Application: Post Genome Related Technology, JPO, Tokyo.

Japan Patent Office (JPO) (2004), Results of the Survey on Intellectual Property-Related Activities, 2003, JPO, Tokyo.

Japan Technomart Foundation (JTM) (2000), Report on Follow up Survey on Patent Licensing Promotion Policy, JTM, Tokyo.

Kalamas, J., G. S. Pinkus and K. Sachs (2002), "The New Math for Drug Licensing”, The Mckinsey Quarterly, 4.

Kaplan, R. S. and D. P. Norton (2004), Strategy Maps: Converting Intangible Assets into Tangible Outcomes, Harvard Business School Press, Boston, Mass. 
Kato, H. (2003), “Technical Standards and Patent Pools: Actual Conditions and Problems”, in Trends of Licensing Agreements in the Industrial Sector and Subsequent Economic Problems, Institute of Intellectual Property, Tokyo.

Köllner, M. (2005), “A Venture Capital Perspective on Patent Valuation and new Regulations”, presentation at EPO-OECD-BMWA International Conference on Intellectual Property as an Economic Asset: Key Issues in Valuation and Exploitation, 30 June-1 July 2005, Berlin, www.oecd.org/sti/ipr.

Kunz, M. (2005), “IP Leverage through Strategic Partnerships of SME with Industry Players”, presentation at EPO-OECD-BMWA International Conference on Intellectual Property as an Economic Asset: Key Issues in Valuation and Exploitation, 30 June-1 July 2005, Berlin, www.oecd.org/sti/ipr.

Layton, R. and P. Bloch (2004), IP Donations: A Policy Review. International Intellectual Property Institute, Washington, DC, www.iipi.org/reports/IP Donations Policy Review.pdf.

Lerner, J., J. Tirole and M. Strojwas (2003), “Cooperative Marketing Agreements between Competitors: Evidence from Patent Pools”, NBER Working Paper 9680.

Marcinkowski, M. (2000), Donating Intellectual Assets.

Motohashi, K. (2005), "Understanding Technology Market: Quantitative Analysis of Licensing Activities in Japan”, presentation at EPO-OECD-BMWA International Conference on Intellectual Property as an Economic Asset: Key Issues in Valuation and Exploitation, 30 June-1 July 2005, Berlin, www.oecd.org/sti/ipr.

Nielsen, P.E. (2004), “Evaluating Patent Portfolios - A Danish Initiative”, World Patent Information 26, $143-148$.

Niemeier, W. (2005), Speech at EPO-OECD-BMWA International Conference on Intellectual Property as an Economic Asset: Key Issues in Valuation and Exploitation, 30 June-1 July 2005, Berlin, www.oecd.org/sti/ipr.

OECD (2002), Science, Technology and Industry Outlook 2002, OECD, Paris.

OECD (2003), Turning Science into Business: Patenting and Licensing at Public Research Organisations, OECD, Paris.

OECD (2004a), Patents and Innovation: Trends and Policy Challenges, OECD, Paris.

OECD (2004b), Networks, Partnerships, Clusters and Intellectual Property Rights: Opportunities and Challenges for Innovative SMEs in a Global Economy, OECD, Paris, www.oecd-istanbul.sme2004.org.

OECD (2004c), Science, Technology and Industry Outlook 2004, OECD, Paris.

OECD (2004d), Intellectual Assets and Business Performance: Background and Issues. Paper prepared for OECD Forum in October 2004, www.oecd.org/sti/ipr.

OECD (2005a), Intellectual Property as an Economic Asset: Key Issues in Valuation and Exploitation. Background and Issues, EPO-OECD-BMWA International Conference on Intellectual Property as an Economic Asset: Key Issues in Valuation and Exploitation, 30 June-1 July 2005, Berlin, OECD, www.oecd.org/sti/ipr. 
DSTI/DOC(2006)5

OECD (2005b), Intellectual Property as an Economic Asset: Key Issues in Valuation and Exploitation. Summary Report, EPO-OECD-BMWA International Conference as an Economic Asset: Key Issues in Valuation and Exploitation, 30 June-1 July 2005, Berlin, OECD, www.oecd.org/sti/ipr.

Otsuyama, H. (2003), "Patent Valuation and Intellectual Assets Management”, Chapter 5, in Samejima, M., ed., Patent Strategy Handbook, Chuokeizai-sha, Tokyo.

Park, W. and D. Lippoldt (2004), "International Licensing and the Strengthening of Intellectual Property Rights in Developing Countries”, OECD document TD/TC/WP(2004)31/FINAL.

Peters, R. (2005), “The Role of IP in the Global Economy”, presentation at EPO-OECD-BMWA International Conference on Intellectual Property as an Economic Asset: Key Issues in Valuation and Exploitation, 30 June-1 July 2005, Berlin.

Picone, T. A. (2002), "Pharmaceutical Licensing during the Revolution”, Chapter 10, in Goldscheider, R., ed., The LESI Guide to Licensing Best Practices, John Wiley \& Sons, New York.

Pitkethly, R. (2002), The Valuation of Patents : A Review of Patent Valuation Methods with Consideration of Option Based Methods and the Potential for Further Research, submitted to High Level Task Force on Valuation and Capitalization of Intellectual Assets organized by the United Nations Economic Commission for Europe (First meeting, 18-19 November 2002).

Pompidou, A. (2005), Speech at EPO-OECD-BMWA International Conference on Intellectual Property as an Economic Asset: Key Issues in Valuation and Exploitation, 30 June-1 July 2005, Berlin, www.oecd.org/sti/ipr.

Razgaitis, R. (2004), “U.S./ Canadian Licensing in 2003: Survey Results”, Les Nouvelles, Journal of the Licensing Executives Society, 39(4), 139-151.

Rivette, K.G. and D. Kline (2000), Rembrandts in the Attic: Unlocking the Hidden Value of Patents, Harvard Business School Press, Boston, Mass.

Rogers, R.S. (1999), “Battling for Blockbusters”, Chemical \& Engineering News, February, 1999.

Roland Berger (2005), Applicant Panel Survey 2004, of Intentions for Filing Patent Applications at the European Patent Office and Other Offices.

Santamauro, J.P. (2005), "Patent Valuation, Exploitation and the Public Sector", presentation at EPOOECD-BMWA International Conference on Intellectual Property as an Economic Asset: Key Issues in Valuation and Exploitation, 30 June-1 July 2005, Berlin, www.oecd.org/sti/ipr.

Schankerman, M. (1998), "How Valuable is Patent Protection? Estimates by Technology Field", The RAND Journal of Economics, 29(1), 77-107.

Schankerman, M. and A. Pakes (1986), "Estimates of the Value of Patent Rights in European Countries during the Post-1950 Period”, The Economic Journal, 96(384),1052-1076.

Scheffer, G.v., D. Loop and St. Lipfert (2005), “From Patents to Finance,” Intellectual Asset Management Magazine, February/March 2005, 37-39.

Secher, D. (2005), “What Makes a Good University Technology Transfer Office?”, presentation at EPOOECD-BMWA International Conference on Intellectual Property as an Economic Asset: Key Issues in Valuation and Exploitation, 30 June-1 July 2005, Berlin, www.oecd.org/sti/ipr. 
Serrano, C.J. (2005), “The Market for Intellectual Property: Evidence from the Transfer of Patents”, Working Paper, University of Toronto.

Shapiro, C. (2001), "Navigating the Patent Thicket: Cross Licenses, Patent Pools, and Standard-Setting”, in Jaffe, A. et al. eds., NBER Innovation Policy and the Economy, 119- 150, MIT Press, Cambridge, Mass.

Sheehan, J., C. Martinez and D. Guellec (2004), "Understanding Business Patenting and Licensing: Results of a Survey", Chapter 4, in Patents, Innovation and Economic Performance - Proceedings of an OECD Conference, OECD, Paris.

Smith, G.V. and R.L. Parr (2000), Valuation of Intellectual Property and Intangible Assets Third Edition, John Wiley \& Sons, New York.

Stern, P.B. (2005), “The Role of Intermediaries in Technology Transfer”, presentation at EPO-OECDBMWA International Conference on Intellectual Property as an Economic Asset: Key Issues in Valuation and Exploitation, 30 June-1 July 2005, Berlin, www.oecd.org/sti/ipr.

Takahashi, T. (2005), Intellectual Assets Strategy and Corporate Accounting, Koubundou Publishers, Tokyo.

Thomson (2004), 2003 Form 20F, www.thomson.net/EN/Home/Investor/AnnualReports.htm.

United States Patent and Trademark Office (USPTO) (2000), Patent Pools: A Solution to the Problem of Access in Biotechnology Patents?, www.uspto.gov/web/offices/pac/dapp/opla/patentpool.pdf.

Vonortas, N.S. and YJ. Kim (2004), “Technology Licensing”, Chapter 10, in Patents, Innovation and Economic Performance - Proceedings of an OECD Conference, OECD, Paris.

Walsh, J. P., A. Arora and W. M. Cohen (2003), "Effects of Research Tool Patents and Licensing on Biomedical Innovation”, in Cohen, W. M. et al., eds., Patents in the Knowledge-Based Economy, The National Academics Press, Washington, DC.

Walsh, J. P., C. Cho and W.M. Cohen (2005), "View from the Bench: Patents and Material Transfers ”, Science, 309, 2002-2003.

Warda, J. (2006), Tax Treatment of Business Investments in Intellectual Assets, An International Comparison, OECD DSTI Working Paper 2006/4.

Washington CORE (2002), "US Survey”, Appendix of Report on Financing in Patent Licensing Market, JTM, Tokyo.

Watanabe, S. (ed) (2002), "Issues of Accounting Surrounding Intellectual Property", Chapter 7, in Intellectual Property - Strategy, Valuation and Accounting, Toyo Keizai, Tokyo.

World Intellectual Property Organisation (WIPO) (2003), "Valuation of Intellectual Property: What, Why and How", WIPO Magazine, 5-8, www.wipo.int/sme/en/documents/wipo_magazine/09_2003.pdf.

Wurzer, A. (2005), “IP and Technology Intermediaries”, presentation at EPO-OECD-BMWA International Conference on Intellectual Property as an Economic Asset: Key Issues in Valuation and Exploitation, 30 June-1 July 2005, Berlin, www.oecd.org/sti/ipr. 
DSTI/DOC(2006)5

Yonetsu, K. (2005), “Activities of the JPO and NCIPI”, presentation at EPO-OECD-BMWA International Conference on Intellectual Property as an Economic Asset: Key Issues in Valuation and Exploitation, 30 June-1 July 2005, Berlin, www.oecd.org/sti/ipr.

Zieger, M. and G.v. Scheffer (2005), "Methods for Patent Valuation”, presentation at EPO-OECD-BMWA International Conference on Intellectual Property as an Economic Asset: Key Issues in Valuation and Exploitation, 30 June-1 July 2005, Berlin, www.oecd.org/sti/ipr. 